\title{
Challenges and opportunities to capture dietary effects in on-farm greenhouse gas emissions models of ruminant systems
}

\section{Article}

Accepted Version

Creative Commons: Attribution-Noncommercial-No Derivative Works 4.0

Vibart, R., de Klein, C., Jonker, A., van der Weerden, T., Bannink, A., Bayat, A. R., Crompton, L., Durand, A., Eugene, M., Clumpp, K., Kuhla, B., Lanigan, G., Lund, P., Ramin, M. and Salazar, F. (2021) Challenges and opportunities to capture dietary effects in on-farm greenhouse gas emissions models of ruminant systems. Science of the Total Environment, 769. 144989. ISSN 0048-9697 doi:

https://doi.org/10.1016/j.scitotenv.2021.144989 Available at https://centaur.reading.ac.uk/96015/

It is advisable to refer to the publisher's version if you intend to cite from the work. See Guidance on citing.

To link to this article DOI: http://dx.doi.org/10.1016/j.scitotenv.2021.144989

Publisher: Elsevier

All outputs in CentAUR are protected by Intellectual Property Rights law, including copyright law. Copyright and IPR is retained by the creators or other copyright holders. Terms and conditions for use of this material are defined in the End User Agreement. 


\section{www.reading.ac.uk/centaur}

\section{CentAUR}

Central Archive at the University of Reading

Reading's research outputs online 
1 Challenges and opportunities to capture dietary effects in on-farm greenhouse gas emissions models of ruminant systems

Ronaldo Vibart' ${ }^{1}$, Cecile de Klein ${ }^{2}$, Arjan Jonker ${ }^{1}$, Tony van der Weerden², André

Bannink $^{3}$, Ali R. Bayat ${ }^{4}$, Les Crompton ${ }^{5}$, Anais Durand ${ }^{6}$, Maguy Eugène ${ }^{7}$, Katja

Klumpp ${ }^{8}$, Björn Kuhla 9 , Gary Lanigan ${ }^{10}$, Peter Lund ${ }^{11}$, Mohammad Ramin ${ }^{12}$, Francisco Salazar $^{13}$

${ }^{1}$ AgResearch Ltd., Grasslands Research Centre, Palmerston North, New Zealand.

${ }^{2}$ AgResearch Ltd., Invermay Agricultural Centre, Mosgiel, New Zealand.

${ }^{3}$ Wageningen Livestock Research, Wageningen University \& Research, Wageningen, The Netherlands.

${ }^{4}$ Production Systems, Natural Resources Institute Finland (Luke), Jokioinen, Finland.

${ }^{5}$ School of Agriculture, Policy and Development, University of Reading, Reading, UK.

${ }^{6}$ CITEPA, 42 rue Paradis, 75010, Paris, France.

${ }^{7}$ UMR Herbivores, INRA, VetAgro Sup, Université Clermont Auvergne, Saint-GenèsChampanelle, France.

${ }^{8}$ UMR Ecosystème Prairial, INRA, Clermont-Ferrand, France.

${ }^{9}$ Institute of Nutritional Physiology, Leibniz Institute for Farm Animal Biology, Dummerstorf, Mecklenburg-Vorpommern, Germany.

${ }^{10}$ Teagasc Agriculture and Food Development Authority, Johnstown Castle Environmental Research Centre, Wexford, Ireland. 
$21{ }^{11}$ Department of Animal Science, AU Foulum, Aarhus University, Blichers Allé 20, DK

228830 Tjele, Denmark

$23 \quad{ }^{12}$ Department of Agricultural Research for Northern Sweden, Swedish University of

24 Agricultural Sciences, Sweden.

$25 \quad{ }^{13}$ Agricultural Research Institute, Remehue Research Centre, Osorno, Chile.

27 Short title: Dairy diet characteristics and on-farm greenhouse gas emission models 
This paper reviews existing on-farm GHG accounting models for dairy cattle systems and their ability to capture the effect of dietary strategies in GHG abatement. The focus is on methane $\left(\mathrm{CH}_{4}\right)$ emissions from enteric and manure (animal excreta) sources and nitrous oxide $\left(\mathrm{N}_{2} \mathrm{O}\right)$ emissions from animal excreta. We identified three generic modelling approaches, based on the degree to which models capture dietrelated characteristics: from 'none' (Type 1) to 'some' by combining key diet parameters with emission factors (EF) (Type 2) to 'many' by using process-based modelling (Type 3). Most of the selected on-farm GHG models have adopted a Type 2 approach, but a few hybrid Type 2 / Type 3 approaches have been developed recently that combine empirical modelling (through the use of $\mathrm{CH}_{4}$ and/or $\mathrm{N}_{2} \mathrm{O}$ emission factors; EF) and process-based modelling (mostly through rumen and whole tract fermentation and digestion). Empirical models comprising key dietary inputs (i.e., dry matter intake and organic matter digestibility) can predict $\mathrm{CH}_{4}$ and $\mathrm{N}_{2} \mathrm{O}$ emissions with reasonable accuracy. However, the impact of GHG mitigation strategies often needs to be assessed in a more integrated way, and Type 1 and Type 2 models frequently lack the biological foundation to do this. Only Type 3 models represent underlying mechanisms such as ruminal and total-tract digestive processes and excreta composition that can capture dietary effects on GHG emissions in a more biological manner. Overall, the better a model can simulate rumen function, the greater the opportunity to include diet characteristics in addition to commonly used variables, and thus the greater the opportunity to capture dietary mitigation strategies. The value of capturing the effect of additional animal feed characteristics on the prediction of on-farm GHG emissions needs to be carefully 
63 balanced against gains in accuracy, the need for additional input and activity data,

64 and the variability encountered on-farm.

65 Keywords: Dairy farm system, Diet, Feeding management, Effluent, Methane,

66 Nitrous oxide.

67

68

69

70

71

72

73

74

75

76

77

78

79

80 
In recent years, there has been an increasing focus on evaluating the environmental effects of livestock production systems, including their impact on greenhouse gas (GHG) emissions. Although debate remains on the precise contribution of ruminant livestock to anthropogenic methane $\left(\mathrm{CH}_{4}\right)$ (Hristov et al., 2018), the role of livestock agriculture as a main contributor to GHG emissions and climate change is undisputed. Climate change and its consequences are currently recognised as one of the major environmental challenges, and the need for GHG mitigation to meet local expectations and international environmental obligations has been globally recognised (Smith et al., 2007). Therefore, it becomes increasingly important to have an enhanced ability to predict on-farm GHG emissions from livestock and assess methods and efficacy of practices to reduce or offset them.

In livestock agriculture, interactions and variability of critical environmental and managerial drivers of GHG emissions contribute to the complexity of extrapolating observed GHG data to a broader range of conditions and scales. Simulation models of on-farm greenhouse gas (GHG) emissions have an important role to play in helping us understand the potential impact of GHG mitigation strategies on farm dynamics, and in using results from experimental measurements of GHG emissions to assess wider implications and potential trade-offs for the system. Models also enable extrapolation of GHG emissions from smaller (i.e., emissions from a site, plot, field, a manure storage facility or from a cow) to larger scales (farm, catchment, region or country) (Schils et al., 2012). In addition to scale, models can also vary depending on the GHG of interest, with some simulating a single GHG (Blaxter and 
Clapperton, 1965; Wilkerson et al., 1995; Benchaar et al., 2001), while other models include all major agricultural GHG (Wheeler et al., 2008; Hillier et al., 2011).

Given the broad range of GHG accounting tools, the complexity of the issue at hand and the increasing need for accounting of on-farm GHG emissions to meet national or global obligations, there is uncertainty amongst agricultural stakeholders as to which tools (calculators, models, modules) are most appropriate to predict GHG emissions from ruminant systems. The amount of GHG produced within a production system needs to be quantified accurately to allow for alternatives to be explored and emissions to be mitigated (Ellis et al., 2010; Benaouda et al., 2019). In addition to the inherent temporal and spatial variability in emissions, the relative advantages and disadvantages of these tools remain to be fully assessed, especially in light of the difficulty in comparing results obtained from different accounting tools, as these vary in conceptual approaches, reporting units and scope.

Feed management decisions are essential for ruminant production systems, as they impact directly on substrate availability for enteric microbial fermentation and digestion, nutritive value, and ruminant excreta composition. In turn, these processes have a strong influence on the amount and profile of agricultural GHG emissions (Henderson et al., 2015). Major sources of GHG emissions from livestock agriculture include methane $\left(\mathrm{CH}_{4}\right)$ emissions from enteric fermentation and stored manure, and nitrous oxide $\left(\mathrm{N}_{2} \mathrm{O}\right)$ emissions from animal excreta. Accordingly, there is an increasing interest in the use of nutrition and feeding management strategies to reduce GHG emissions. A range of nutritional and feeding management options for $\mathrm{CH}_{4}$ abatement (Beauchemin et al., 2008; Martin et al., 2010; Caro et al., 2016; Pellerin et al., 2017) and $\mathrm{N}_{2} \mathrm{O}$ abatement (de Klein and Eckard, 2008; Monaghan and 
de Klein, 2014) have been described. Examples of nutrition strategies that have shown promising results in mitigating GHG emissions include increasing grain levels (i.e., greater concentration of degradable starch and soluble carbohydrates in the diet), inclusion of lipids and dietary tannins, reducing dietary crude protein, improving feed digestibility and altering the stage of maturity of harvested forages.

In 2017, a three-year project commenced to bring together the current knowledge on the effect of feed and dietary management on GHG emissions: Capturing the Effects of Diet on Emissions from Ruminant Systems (CEDERS;

https://www.eragas.eu/en/eragas/Research-projects/CEDERS-1.htm). The main goal of the project was to examine dietary effects on on-farm GHG emissions and their trade-offs, both at the farm and national scales, with the overall aim of supporting GHG mitigation research and aligning national agricultural GHG inventory research across a consortium of ten countries (Chile, Denmark, Finland, France, Germany, Ireland, Netherlands, New Zealand, Sweden and United Kingdom). Our review is part of this project with the specific objectives to a) identify the most common onfarm GHG accounting tools used by the participant countries, and once identified, b) explore the livestock GHG accounting approach used by these tools, and c) explore the potential benefits of adding diet characteristics to on-farm GHG accounting tools for dairy systems. The focus is on $\mathrm{CH}_{4}$ emissions from enteric fermentation and manure (animal excreta) and $\mathrm{N}_{2} \mathrm{O}$ emissions from animal excreta as on-farm $\mathrm{GHG}$ sources.

\section{Modelling GHG emissions from ruminant enterprises}

Methane and $\mathrm{N}_{2} \mathrm{O}$ are colourless and odourless GHG that are 28 and 265 times more potent (100-year horizon) than $\mathrm{CO}_{2}$ at warming the earth (Myhre et al., 2013). 
152 Enteric and manure $\mathrm{CH}_{4}$ emissions from ruminants, and $\mathrm{N}_{2} \mathrm{O}$ emissions from animal excreta are the main GHG from livestock agriculture. The contribution of $\mathrm{CO}_{2}$ emissions from energy sources and input use are frequently added to GHG budgets, often using a life cycle assessment (LCA) approach. Many mathematical models have been developed to predict these major on-farm GHG.

With a focus on the two main GHG from animal livestock systems $\left(\mathrm{CH}_{4}\right.$ and $\left.\mathrm{N}_{2} \mathrm{O}\right)$, different types of models have been developed to predict emissions of these gases. These models vary in the level of detail they capture and range from relatively simple 
the extent to which polluting end points are affected (e.g., $\mathrm{N}$ in freshwater bodies), are harder to capture, and as a consequence, these equations can still be poor predictors of GHG emissions at a specific farm scale. At the dairy farm scale, a greater complexity with integrated components such as livestock, manure management, housing conditions (barn or on pasture), soil management, and pasture and fodder crop production need to be incorporated in the modelling (Ellis et al., 2010).

\section{Models of on-farm GHG emissions}

In addition to models used for GHG inventories (e.g., Ministry for Primary Industries, 2019) and those used for carbon cycle assessments (e.g., Cowie et al., 2012), Denef et al. (2012) classified GHG tools into four major categories: calculators, protocols, guidelines and models. The focus of this review is on on-farm calculators and farmscale models (herein on-farm GHG models) that have been either developed to aid in the representation of enteric fermentation (the prevalent source of GHG from ruminant systems), or that aim to quantify GHG emissions from ruminants (or improve prediction capacity), under varying animal nutrition conditions.

To date, a large number of on-farm GHG models have been developed for use by farmers, farm consultants, environmental authorities and the scientific community.

On-farm GHG models can help with i) estimating total emissions for accounting purposes, raising awareness, ii) identifying, developing and encouraging adoption of mitigation strategies, iii) identifying knowledge gaps, and creating and exploring current and alternative scenarios, and iv) scaling-up information, and making future projections and policy development (Smith et al., 2007; Colomb et al., 2012; Milne et al., 2013). 
200 On-farm GHG models offer a broad diversity of scope (i.e., from single GHG to

201

202

203

204

205

206

207 integral assessment of all three major GHG), modelling approach adopted (i.e., from simple empirical approaches to more complex dynamic or process-based models), scale (i.e., from the rumen, soil plot and manure scale to global scale) and emissions source (i.e., horticulture, grazing and livestock, grasslands, orchards, forestry, and other land uses) (Hall et al., 2010; Schils et al., 2012). Although models tend to be characterised as being empirical or mechanistic, often both approaches are followed for different components within a single model. In general, farm-scale models tend to follow hybrid or empirical approaches at wider scopes and at various scales to integrate soil, crop and livestock components into a farm framework (Schils et al., 2012).

The degree to which diet ingredients and diet chemical composition are captured in on-farm GHG models varies considerably. The first step at the animal level of most on-farm models is to estimate daily DMI per animal, derived from estimated animal energy requirements (often based on BW, maintenance needs, tissue growth, milk production, pregnancy, and activity) divided by the energy concentration of the feed. The gross energy (GE; in megajoules MJ) concentration of a feed can be calculated based on crude protein (CP), ether extract $(\mathrm{EE})$, neutral detergent fibre (NDF) and non-fibre carbohydrate (NFC) concentrations. The major component of metabolisable energy (ME) or net energy (NE) of a feed is digestible energy (DE). The DE value of a feed can be estimated from organic matter digestibility (OMD), or from feed chemical composition (from similar components as used for calculation of GE) and corresponding digestibility coefficients published in feed tables for individual ingredients (Beyer et al., 2003; Blok and Spek, 2016; Rinne et al., 2017). Feed DE can also be estimated using prediction equations (NRC, 2001) or be based on a 
combination of chemical composition data and prediction equations (Fox et al., 2004). These DE or OMD values are often used to calculate total faecal OM output or volatile solids (VS), which are the source of manure $\mathrm{CH}_{4}$ emissions. However, some more advanced models predict DE, OMD, VS and N digestibility (ND) mechanistically (Illius and Gordon, 1991; Bannink et al., 2018, 2020).

The second step of the animal level model comprises the calculation of a $\mathrm{CH}_{4}$ conversion factor (MCF or $\mathrm{Y}_{\mathrm{m}}$ ), which can involve a) multiplying DMI or GE intake (GEI) with a fixed conversion factor [e.g., MCF (\% of GE) $=6.5 \pm 1.0 \%$ of GEI (IPCC, 2006)], b) the use of a generic equation, that might include dietary ingredients (e.g., forage and concentrate), chemical composition parameters (e.g., EE, NDF, starch) and digestibility parameters (e.g., OMD) (Nielsen et al., 2013; Jaurena et al., 2015; Eugène et al., 2019), or c) the use of a dynamic and mechanistic model with representation of rumen fermentation and gastrointestinal digestion (Bannink et al., 2011; Beukes et al., 2011; Huhtanen et al., 2015). Input parameters for these dynamic, mechanistic models include DMI, diet chemical composition and ruminal and total tract digestive parameters (Table 1). In these models, rumen $\mathrm{H}_{2}$ formation is derived from fermented amounts of substrate and associated volatile fatty acid (VFA) stoichiometry (e.g., Bannink et al., 2011; Huhtanen et al., 2015).

The third and final step in capturing dietary effects in on-farm GHG models is an estimation of $\mathrm{CH}_{4}$ and $\mathrm{N}_{2} \mathrm{O}$ emissions from manure storage, land application of manure and direct deposition of faeces and urine by grazing animals. Both $\mathrm{CH}_{4}$ and $\mathrm{N}_{2} \mathrm{O}$ emissions from manures are not only influenced by diet characteristics but also by biotic and abiotic factors such as manure storage, soil and climatic conditions. Here we focus on the influence of diet. Manure $\mathrm{CH}_{4}$ emissions are strongly linked to 
the VS content of the manure and as mentioned above this is often estimated from DE or OMD values. Nitrous oxide emissions are calculated from the amount of $\mathrm{N}$ excreted as faeces and urine multiplied by an emission factor (IPCC, 2006). Nitrogen excretion estimates require information on DMI per animal and CP or $\mathrm{N}$ concentration of the diet (IPCC, 2006) (Figure 1), where the $\mathrm{N}$ concentration of the diet also influences partitioning of excreta $\mathrm{N}$ into faeces and urine (IPCC, 2019). Excretion estimates can be refined further by accounting for improved estimates of apparent faecal ND. Nitrous oxide emission factors will differ according to the method of manure management and, for excreta, the livestock type (e.g., cattle vs. sheep) and form of excreta (faeces vs. urine) (IPCC, 2006).

\section{On-farm GHG model approaches to capture dietary effects on GHG} emissions from livestock systems

In most ruminant systems, $\mathrm{CH}_{4}$ is the predominant source of $\mathrm{GHG}$ emissions, with the diet having a major impact on enteric $\mathrm{CH}_{4}$ from fermentation of feed in the rumen; the latter is the prevailing GHG source. For the two most important GHG approach chosen. The three approaches we identified are:

- A Type 1 approach has a very low level of detail and uses a $\mathrm{CH}_{4}$ emission factor (EF) per animal and an $\mathrm{N}_{2} \mathrm{O}$ EF per unit of animal excreta, similar to a Tier 1 level at a national scale (IPCC, 2006). 
- A Type 2 approach has an intermediate level of detail (Figure 1). It estimates the energy requirements of the animal (often in terms of ME or NE) based on milk, meat and fibre production, and animal characteristics. These requirements are then used to estimate feed DMI; enteric $\mathrm{CH}_{4}$ emissions are then estimated using a $\mathrm{CH}_{4} \mathrm{EF}\left(\mathrm{g} \mathrm{CH}_{4} \mathrm{~kg}^{-1} \mathrm{DMI}\right)$.

- A Type 3 approach has a higher level of detail that often involves process-based modelling, taking into account DMI, diet chemical composition and nutrient supply, along with feed degradation and fermentation characteristics to predict (rather than assume) $\mathrm{CH}_{4} \mathrm{EF}$ according to a mechanistic, dynamic representation.

Type 1 models that use a default EF per animal or per unit of excreta $\mathrm{N}$ are not commonly used for on-farm GHG accounting or LCA, and generally only serve at a national level for inventory purposes. However, some on-farm GHG accounting models use country-, region- or farm-specific EF and apply these to the number of animals (e.g., $\mathrm{kg} \mathrm{CH}_{4}$ animal ${ }^{-1}$ year ${ }^{-1}$ ) or the amount of excreta $\mathrm{N}$ (e.g., $\mathrm{kg} \mathrm{N}_{2} \mathrm{O}-\mathrm{N} \mathrm{kg}^{-1}$ $\mathrm{N}$ excreted) (diversified Type 1 models; herein Type 1+ models). The EF for these Type 1+ models can be derived from experimental data (e.g., van der Weerden et al., 2011; Chadwick et al., 2018) or from detailed process-based modelling that could also provide look-up tables of EF (e.g., based on farm system, animal type or region) for such Type 1+ models. Type 1 models that use IPCC default values cannot capture dietary effects as $\mathrm{CH}_{4}$ and $\mathrm{N}$ excreta $\mathrm{EF}$ are provided for an average animal. However, Type 1+ models could capture dietary effects if experimental data or results from process-based models deliver different EF estimates for an animal (or per unit of $\mathrm{N}$ excreta) consuming different diets. 


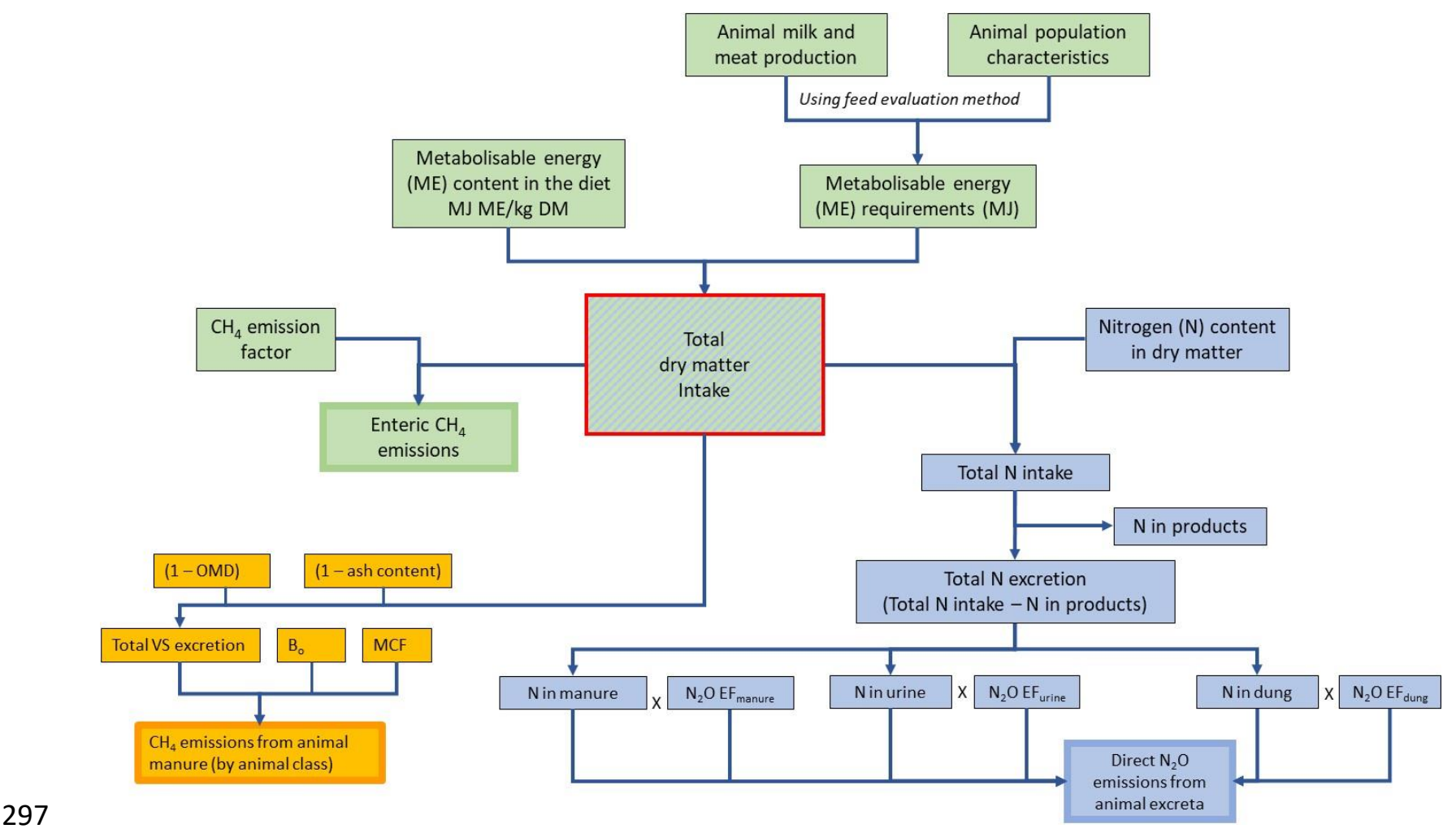

298 Figure 1. Schematic overview of a generic Type 2 approach for estimating methane $\left(\mathrm{CH}_{4}\right)$ and nitrous oxide $\left(\mathrm{N}_{2} \mathrm{O}\right)$ emissions from livestock production systems (modified from de Klein et al., 2019). Green boxes refer to enteric $\mathrm{CH}_{4}$, orange boxes to manure $\mathrm{CH}_{4}$, and blue boxes to $\mathrm{N}_{2} \mathrm{O}$. $\mathrm{ME}$ = metabolisable energy; $\mathrm{MJ}=$ mega joules; $\mathrm{OMD}=$ organic matter digestibility; $\mathrm{VS}=$ volatile solids; $\mathrm{B}_{0}=$ maximum $\mathrm{CH}_{4}$ producing capacity of manure; $\mathrm{MCF}=\mathrm{CH}_{4}$ conversion factor; $\mathrm{EF}=$ emission factor. The efficiency of use of feed energy and protein modulate these fluxes.

For Type 2 models, a number of alternative approaches have been followed. These include either a) models that calculate energy requirements to estimate DMI with fixed EF and $\mathrm{N}$ excreta values, with or without different EF values for different stock classes (e.g., Wheeler et al., 2008), b) models that use prediction equations for enteric $\mathrm{CH}_{4}$ emissions or for EF estimates based on feeding level, dietary proportion of concentrate and OM digestibility (OMD) from a large literature database (e.g., 
311 Eugène et al., 2019), or c) a purely experimentally-driven (empirical) estimate of EF

312 rather than a meta-analysis (e.g., Hellwing et al., 2016).

313 For models using Type 2a approaches, the opportunities to capture GHG abatement

314 from ruminants using diet characteristics are limited. The use of sole indicators of

315 diets or diet components feeding values such as ME, often calculated from chemical composition and OMD (irrespective of feeding level), limits the possibilities of GHG mitigation via nutritional strategies (Waghorn, 2007; Niu et al., 2018). This approach tends to use animal-, rather than feed-driven EF, and appears less accurate in accounting for changes in diet and diet characteristics other than by changes in feeding value. A more detailed alternative to this approach is the use of specific dietary ingredient EF (i.e., different EF for concentrates, supplements and fresh forages). Following this approach, emissions from enteric fermentation are calculated using different EF ( $\left.\mathrm{g} \mathrm{CH}_{4} \mathrm{~kg}^{-1} \mathrm{DMI}\right)$ values for concentrates, maize silage and grass products (Schils et al., 2006), most likely obtained from respiration chambers. Type $2 b$ models have a few more opportunities to capture GHG abatement using diet characteristics. However, these are limited to the predictor variables included in the empirical enteric $\mathrm{CH}_{4}$ equation (feeding level, OMD and dietary proportion of concentrate) and the characterisation of non-digestible OM (CP, $\mathrm{NDF}$, starch, $\mathrm{C} / \mathrm{N}$ ratio) and $\mathrm{N}$ excretion (urinary and faecal), and its effect on manure EF (INRA, 2018; Eugène et al., 2019). Finally, models that follow Type 2c approaches have greater opportunities to explore GHG abatement using diet characteristics by using different EF based on experimental studies. For example, some experiments have shown that an increased concentration of starch and fat in the diet resulted in a significantly lower $\mathrm{CH}_{4}$ conversion factor (MCF, \% of GEI)

335 (Hellwing et al., 2016; Niu et al., 2018; Sauvant et al., 2018). 
Alternatively, process-based models could be used to provide diet-specific EF. For example, Bannink et al. (2020) recently derived lookup tables for specific EF for feeds and dietary ingredients for a range of diet classes (classified according to the proportion of maize silage in forage DM) and estimating DMI from process-based modelling. In this way, the essence of variation predicted by a process-based modelling approach (Type 3) was introduced by differentiation of EF values and correction for DMI and diet class in an otherwise typical Type 2a approach.

In all Type 2 models, estimates of DMI, along with the $\mathrm{N}$ concentration of the feed, are used to estimate animal $\mathrm{N}$ intake, which provides the basis for estimating $\mathrm{N}$ excretion in urine, faeces and manure effluent. Nitrous oxide emissions from these sources are then estimated using source-specific EF (e.g., Wheeler et al., 2008). Furthermore, to explore GHG abatement, the partition between faecal and urinary $\mathrm{N}$ fluxes derived from $\mathrm{N}$ intake can be estimated (INRA, 2018) along with $\mathrm{CH}_{4}$ emissions for some mitigating strategies (e.g., for forage diets by Sauvant et al., 2014 in the INRA Method; for various diets by deriving an ND correction factor by Bannink et al., 2018 in DairyWise).

A Type 3 approach considers the effect of feed intake, feed chemical composition, ruminal degradation characteristics and end-products of fermentation, as well as rumen fermentation conditions and physical inflows and outflows of nutrients, to estimate enteric $\mathrm{CH}_{4}$ emissions (e.g., Bannink et al., 2011; Beukes et al., 2011; Huhtanen et al., 2015). This is often achieved using process-based (mechanistic) models that focus on detailed biological and physical processes with explicit mechanisms being represented, in contrast to the empirical approaches with Type 2 
models which are typically simpler, and the mechanisms are made implicit to the model.

Nitrous oxide emissions are largely estimated as for Type 2, but feed characteristics are used to estimate faecal $\mathrm{N}$ digestibility and $\mathrm{N}$ returned to the different soil $\mathrm{N}$ pools and processes (Bannink et al., 2018; INRA, 2018). In this way, Type 3 approaches allow for dietary ingredients, feed composition and digestion kinetics to be considered not only for $\mathrm{CH}_{4}$ but also for $\mathrm{N}$ excretion and associated $\mathrm{N}_{2} \mathrm{O}$ accounting and mitigation.

\section{Selected on-farm GHG models}

We have selected a number of (on-farm and animal) models from CEDERS participant countries, mostly based on degree of adoption and use, and on published literature. Information on these models was either publicly available or provided by experienced users. A brief description of the selected models is provided as Supplementary Material. The source of the model, the inclusion of diet characteristics and digestion kinetics in calculating enteric $\mathrm{CH}_{4}$, are described in Table 1. Similarly, the inclusion of diet characteristics in calculating manure-derived $\mathrm{CH}_{4}$ and $\mathrm{N}_{2} \mathrm{O}$ from $\mathrm{N}$ excreta, are presented in Table 2.

\subsection{Brief summary of the models}

Most of the selected on-farm GHG models have adopted a Type 2 approach, generally using $\mathrm{CH}_{4}$ and $\mathrm{N}_{2} \mathrm{O}$ emission factors (EF) or a $\mathrm{CH}_{4}$ conversion factor (MCF). Recently, a few hybrid Type 2 / Type 3 approaches have been developed that combine empirical modelling (through the use of $\mathrm{CH}_{4}$ or $\mathrm{N}_{2} \mathrm{O} \mathrm{EF}$ ) and processbased modelling, mostly of rumen and whole tract fermentation and digestion. 
Obtaining an accurate estimation of DMI is an essential first step to obtain accurate GHG predictions, because this variable is such an overriding factor in enteric $\mathrm{CH}_{4}$ emissions. It also leads to predictions of OM excretion (i.e., VS), manure $\mathrm{CH}_{4}$ emissions, and to predictions of $\mathrm{N}$ excretion, in turn a major predictor of $\mathrm{N}_{2} \mathrm{O}$ emissions. Estimates of DMI in these models are often obtained from either feed tables or nutrition models (energy based or protein-plus-energy based) (e.g., Scandinavian feed units in FarmGHG; the NEL system in GAS-EM; CSIRO (2007) in OverseerFM) (Type 2 approach) or as an outcome of more sophisticated models. In experimental settings, measuring feed on offer vs feed refused (housing systems), inference from animal performance (housing and grazing systems), and the use of markers and estimates from herbage disappearance (grazing systems), are commonly used to obtain estimates of DMI. In turn, the information collected in these settings provides a feedback loop to keep feed tables, nutrition models and ruminant models relevant and updated.

A second step in this process is the attainment of adequate $\mathrm{EF}$ (i.e., $\mathrm{CH}_{4}$ per unit of DMI and per unit of faeces at grazing, $\mathrm{CH}_{4}$ and $\mathrm{N}_{2} \mathrm{O}$ per unit of animal excreta). Emission factors are often obtained from either literature surveys, databases of experimental data, or based on predictions of process-based models that are able to be explanatory and consider further detail. The choice will depend on country- or region-specific data availability and the possibility of adapting and validating the later models to country- or region-specific conditions.

A subtle distinction can be made between empirical GHG prediction models that potentially represent the most relevant results obtained from experimental work, and mechanistic models that attempt to grasp the underlying mechanisms and 
406 processes. In ruminants, enteric $\mathrm{CH}_{4}$ is primarily produced in the rumen $(87 \%$ of total 407 enteric $\mathrm{CH}_{4}$ production) and to a lesser extent in the large intestine (the remaining 408 13\%) (Murray et al., 1976; Torrent and Johnson, 1994; discussed in Ellis et al., 409 2008). The closer the models are at interpreting and simulating rumen function 410 (ruminal degradation characteristics and end-products of fermentation), the greater 411 the opportunity to capture diet characteristics beyond the sole variables OM or DM 412 intake, and to capture dietary mitigation alternatives. 


\begin{tabular}{|c|c|c|c|}
\hline \multirow{2}{*}{$\begin{array}{l}\text { Model (main source), } \\
\text { country, and model type }\end{array}$} & \multicolumn{3}{|l|}{ Feed characteristics and processes used for enteric $\mathrm{CH}_{4}$ calculations } \\
\hline & Feed components and feed characteristics & Digestion kinetics & Enteric $\mathrm{CH}_{4}$ calculation \\
\hline $\begin{array}{l}\text { Karoline (Danfær et al., } \\
\text { 2006) - Denmark / } \\
\text { Sweden. } \\
\text { Type } 3 \text { model. }\end{array}$ & $\begin{array}{l}\text { Forage (for) pdNDF, concentrate (con) pdNDF, for iNDF, con } \\
\text { iNDF, starch, lactic acid, } \mathrm{NH}_{3}-\mathrm{N} \text {, free aa, peptides, soluble } \mathrm{CP} \text {, } \\
\text { insoluble } \mathrm{CP} \text {, pdCP, for } \mathrm{EE} \text {, con EE, rest fraction [DM - (ash + } \\
\mathrm{NDF}+\text { starch + lactic acid + VFA + CP + EE)] (contains WSC, } \\
\text { pectins, organic acids, alcohols). VFA for silages. }\end{array}$ & $\begin{array}{l}\text { Feed-specific digestion rates }(\mathrm{kd}) \text { for } \\
\text { pdNDF, insoluble CP and starch. } \\
\text { Digestion rate (Kd) of pdNDF } \\
\text { adjusted for dietary NFC and } \\
\text { feeding level. }\end{array}$ & $\begin{array}{l}\text { Rumen } \mathrm{H}_{2} \text { based on VFA } \\
\text { stoichiometry from fermented feed, } \\
\text { adjusted for feeding level. } \mathrm{H}_{2} \text { pool } \\
\text { adjusted for microbial mass and } \mathrm{BH} \text {. } \\
\text { Includes } \mathrm{CH}_{4} \text { formation in hind gut. }\end{array}$ \\
\hline $\begin{array}{l}\text { FarmGHG (Olesen et al., } \\
\text { 2006) - Denmark. } \\
\text { Type } 2 \text { model. }\end{array}$ & CF, NFE, CP, and fat daily intake $\left(\mathrm{kg} \mathrm{d}^{-1}\right)$ & & $\begin{array}{l}\text { Empirical equation (Kirchgessner et } \\
\text { al., 1995). }\end{array}$ \\
\hline $\begin{array}{l}\text { Valio Carbo® Farm } \\
\text { calculator - Finland. } \\
\text { Type } 2 \text { model. }\end{array}$ & $\begin{array}{l}\text { DMI, OMI, GE, ME, DM, ash, OMD, FOM, CP, EPD, EE, NDF, } \\
\text { iNDF, AAT, feed-AAT; PBV, NFC, NFC/CHO lactic acid, VFA, } \\
\left.\text { ammonia (g kg }{ }^{-1} \mathrm{~N}\right), \mathrm{Ca}, \mathrm{P}, \mathrm{Na}, \mathrm{Mg}, \mathrm{K}, \mathrm{S}, \mathrm{Cl}, \mathrm{Fe}, \mathrm{Cu}, \mathrm{Zn}, \mathrm{Mn}, \mathrm{I} \text {, } \\
\text { Co, Mo, Se, WSC, starch, iNDF, CF, NFE. }\end{array}$ & $\begin{array}{l}\text { Digestibility of CP, EE, CF, NFE, } \\
\text { OM. }\end{array}$ & $\begin{array}{l}\text { Empirical equations (Ramin and } \\
\text { Huhtanen, 2013). }\end{array}$ \\
\hline $\begin{array}{l}\text { FarmSim (Graux et al., } \\
\text { 2011) - France. } \\
\text { Type } 2 \text { model. }\end{array}$ & $\begin{array}{l}\text { For and con NDF, digestibility. } \\
\text { Grazing: adjusted for dietary NE intake and animal needs. }\end{array}$ & & $\begin{array}{l}\text { IPCC Tier } 1 \text { (274 and } 279 \mathrm{~g} \mathrm{CH}_{4} \mathrm{~d}^{-1} \\
\text { for European and Dutch dairy cows, } \\
\text { respectively) and Tier } 2 \text { (MCF = } 6 \% \\
\text { of dietary GEI) (IPCC, 1996). }\end{array}$ \\
\hline $\begin{array}{l}\text { INRA Method (Eugène et } \\
\text { al., 2019) - France. } \\
\text { Type } 2 / 3 \text { model. }\end{array}$ & $\begin{array}{l}\text { Not a farm-scale model, but used to progress from Tier } 2 \text { to } \\
\text { Tier } 3 \text { at a national scale. } \\
\text { Energetic requirements: GE, DE, NEL. Feed characteristics: } \\
\text { DM, OM, CP, NDF, OMD, PC, N balance in the rumen. }\end{array}$ & $\begin{array}{l}\text { Digestibility of OM, NDF, CP, starch, } \\
\mathrm{N} \text {. Digestive interactions driven by } \\
\text { feeding level, DMl and BW. Also } \\
\text { includes digestion rates (kd), N and } \\
\text { energy use efficiencies. }\end{array}$ & $\begin{array}{l}\text { Empirical equations (Sauvant and } \\
\text { Nozière, 2016). Mitigation options } \\
\text { (Sauvant et al., 2018). }\end{array}$ \\
\hline $\begin{array}{l}\text { GAS-EM (Haenel et al., } \\
\text { 2020) - Germany. } \\
\text { Type } 2 \text { model. }\end{array}$ & $\begin{array}{l}\mathrm{GE}, \mathrm{DE}, \mathrm{NEL}, \mathrm{DM}, \mathrm{OM} \text {, ash, } \mathrm{CP} \text { (and/or N); OMD, CF, NFE, } \\
\text { and fat. No differentiation by seasons and regions. }\end{array}$ & & $\begin{array}{l}\text { Empirical equation (Kirchgessner et } \\
\text { al., 1994). }\end{array}$ \\
\hline $\begin{array}{l}\text { The GHG model (O'Brien } \\
\text { et al., } 2010) \text { - Ireland. } \\
\text { Type } 2 \text { model. }\end{array}$ & $\begin{array}{l}\text { Dairy cows on conserved forage: proportion of forage in the } \\
\text { diet and total DMI. } \\
\text { Dairy cows on fresh grass: } 0.065 \times \text { GEI (IPCC, 2006). }\end{array}$ & & $\begin{array}{l}\text { Empirical equations (Mills et al., } \\
\text { 2003; IPCC, 2006). }\end{array}$ \\
\hline $\begin{array}{l}\text { DairyWise (Schils et al., } \\
\text { 2007) - Netherlands. } \\
\text { Type } 2 / 3 \text { model. }\end{array}$ & $\begin{array}{l}\text { Different EF for con, maize silage and grass products (20, } 22 \\
\text { and } 27 \mathrm{~g} \mathrm{CH}_{4} \mathrm{~kg}^{-1} \text { DMI, respectively). Updated (Bannink et al., } \\
2020) \text { with EF for different feeds (con ingredients, for qualities } \\
\text { and diet types; the latter based on \% maize silage in dietary } \\
\text { for) derived from Dairy Tier } 3 \text { simulation. }\end{array}$ & & $\begin{array}{l}\mathrm{CH}_{4} \mathrm{EF} \times \text { animal intake (Schils et } \\
\text { al., 2006). } \\
\text { Updated and corrected } \mathrm{CH}_{4} \mathrm{EF} \\
\text { values (Bannink et al., 2020). }\end{array}$ \\
\hline $\begin{array}{l}\text { Dairy Tier } 3 \text { (Dijkstra et } \\
\text { al., 1992; Bannink et al., } \\
\text { 2011) - Netherlands. } \\
\text { Type } 3 \text { model. }\end{array}$ & $\begin{array}{l}\text { DMI, aNDFom, starch, SC, CP, non-ammonia CP, crude fat, } \\
\text { ash, organic acids (for silages, lactic acid and VFA), and non- } \\
\text { allocated OM, now allocated to sugars, starch and aNDFom } \\
\text { depending on the ingredient type. }\end{array}$ & $\begin{array}{l}\text { In situ degradation of aNDFom, } \\
\text { starch and CP for each diet } \\
\text { ingredient [washable fraction (W), } \\
\text { potentially degradable (D), and }\end{array}$ & $\begin{array}{l}\text { Rumen } \mathrm{H}_{2} \text { based on VFA } \\
\text { stoichiometry from fermented } \\
\text { substrate (SC, starch, } \mathrm{HC}, \text { Ce and } \\
\mathrm{CP} \text { ) with an adjustment for dietary }\end{array}$ \\
\hline
\end{tabular}
20 


$\begin{array}{ll}\text { OverseerFM (Wheeler et } & \text { DM digestibility, ME and N of pastures and supplements. } \\ \text { al., 2008) - New } & \text { Animal ME requirement from feeding standards (mostly }\end{array}$

$\begin{array}{ll}\text { al., 2008) - New } & \text { Animal ME requir } \\ \text { Zealand. } & \text { CSIRO, 2007). }\end{array}$

Type 2 model.

Whole Farm Model

(WFM) (Beukes et al.

2010) - New Zealand

Type 3 model.

Arla Carbon tool, Arla

Foods - Sweden

Denmark / Germany /

United Kingdom.

Type 2 model.

NorFor (Nielsen et al., $\quad$ DMl and dietary FA and NDF.

2013) - Sweden /

Denmark.

Type 2 model.

SIMS DAIRY (del Prado et $\mathrm{DMI}\left(\mathrm{g} \mathrm{kg}^{-1} \mathrm{BW} \mathrm{d}^{-1}\right.$ and $\left.\mathrm{kg} \mathrm{d}^{-1}\right), \mathrm{C} 18: 2$ (quantity of linoleic acid in

al., 2011) - UK.

Type 2 model.

Farmscoper (Gooday et DMI, ME.

al., 2014) - UK.

Type 2 model.

AgRE Calc - UK.

Type 2 model.

Soluble ash, $\mathrm{Ce}, \mathrm{HC}, \mathrm{SC}$, uFA, starch, large particles in the

rumen, lignin, insoluble protein, $A A$, ammonia.

GE intake, either specified by the farmer or calculated based

on NorFor for cows and IPCC (2006) for heifers and bulls, and

FA. rumen undegradable $(\mathrm{U})$ fraction and fractional degradation rate $(\mathrm{kd})$ of D].

for-to-con ratio. $\mathrm{H}_{2}$ pool adjusted for microbial growth on $\mathrm{AA}$ or $\mathrm{NH}_{3}-\mathrm{N}$, and for $\mathrm{BH}$ of $\mathrm{UFA}$. $\mathrm{EF}\left(21.6 \mathrm{~g} \mathrm{CH}_{4} \mathrm{~kg}^{-1} \mathrm{DMI}\right) \times$ animal intake (IPCC, 2006; Ministry for Primary Industries, 2019).

Enteric $\mathrm{CH}_{4}$ calculation based on $\mathrm{H}_{2}$ balance from $\mathrm{H}_{2}$ formation from $\mathrm{CHO}$ and $A A$ fermentation, microbial growth, BH of UFA, and VFA profile. associated with starch and $(\mathrm{Ce}+$ $\mathrm{HC}$ ) fermentation. Ruminal acetate, propionate, butyrate and lactate.

Digestibility coefficients: DM, CP, $\mathrm{CF}$, structural and non-structural carbohydrates, FA, DE.

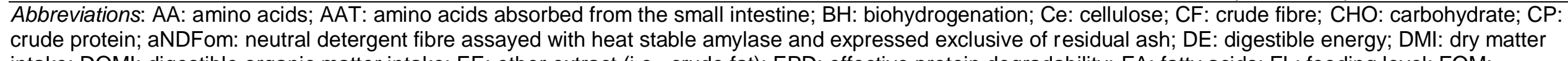
intake; DOMI: digestible organic matter intake; EE: ether extract (i.e., crude fat); EPD: effective protein degradability; FA: fatty acids; FL: feeding level; FOM: fermentable organic matter; GE: gross energy; GEI: gross energy intake; HC: hemicellulose; iNDF: indigestible neutral detergent fibre; kd: fractional degradation

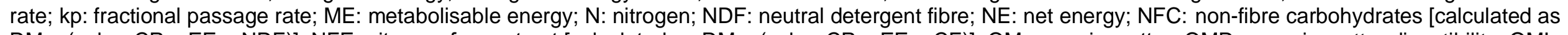

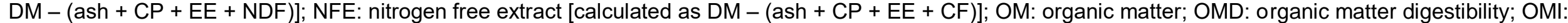
organic matter intake; PBV: protein balance in the rumen; PC: proportion of concentrate in the diet; pdCP: potentially digestible CP; pdNDF: potentially digestible NDF; uFA: unsaturated FA; VFA: volatile fatty acids; WSC: water soluble carbohydrates. 
427 Table 2. Summary of the approaches used for estimating methane $\left(\mathrm{CH}_{4}\right)$ and nitrous oxide $\left(\mathrm{N}_{2} \mathrm{O}\right)$ emissions from manure (including urine and faeces deposited during grazing) and feed characteristics captured in selected on-farm models.

\begin{tabular}{|c|c|c|c|}
\hline $\begin{array}{l}\text { Model (source) and } \\
\text { country }\end{array}$ & Manure $\mathrm{CH}_{4}$ (including faeces from grazing) & $\begin{array}{l}\text { Manure } \mathrm{N}_{2} \mathrm{O} \text { (including urine and faeces from } \\
\text { grazing) }\end{array}$ & Feed characteristics captured in the model \\
\hline $\begin{array}{l}\text { FASSET (Olesen et al., } \\
\text { 2002) - Denmark. }\end{array}$ & Does not include estimates of manure $\mathrm{CH}_{4}$. & $\begin{array}{l}\text { Estimates manure } \mathrm{N}_{2} \mathrm{O} \text { using semi-empirical } \\
\text { equations that calculate nitrification and } \\
\text { denitrification, and partition the end-products } \\
\text { into } \mathrm{N}_{2} \text { and } \mathrm{N}_{2} \mathrm{O} \text {. }\end{array}$ & Dietary N. \\
\hline $\begin{array}{l}\text { FarmGHG (Olesen et al., } \\
\text { 2006) - Denmark. }\end{array}$ & $\begin{array}{l}\text { IPCC Tier 2: calculates annual } \mathrm{CH}_{4} \mathrm{EF} \text { based } \\
\text { on VS excretion, } \mathrm{B}_{0} \text {, and MCF (for three } \\
\text { housing and four storage systems) but uses } \\
\text { country specific values and also includes } \\
\text { temperature and storage time functions. }\end{array}$ & $\begin{array}{l}\text { Estimates } \mathrm{N}_{2} \mathrm{O} \text { for three housing and four } \\
\text { storage systems as a function of temperature } \\
\text { and/or storage time and/or tank surface area. }\end{array}$ & Dietary $\mathrm{N}$. \\
\hline $\begin{array}{l}\text { Valio Carbo® Farm } \\
\text { calculator - Finland. }\end{array}$ & $\begin{array}{l}\text { Algorithm by Sommer et al. (2004) and } \\
\text { applying experimentally derived parameters } \\
\text { for stored slurry (Elsgaard et al., 2016; } \\
\text { Petersen et al., 2016). }\end{array}$ & $\begin{array}{l}\text { EF used for calculation of } \mathrm{N}_{2} \mathrm{O} \text { from } \\
\text { EMEP/EEA (2016) and IPCC (2006) } \\
\text { (Grönroos et al., 2017). }\end{array}$ & Total N, VSD, ash, water, P, TAN, FOM, K. \\
\hline $\begin{array}{l}\text { FarmSim (Salètes et al., } \\
\text { 2004; Graux et al., 2011) } \\
\text { - France. }\end{array}$ & $\begin{array}{l}\text { IPCC Tier } 2 \text { for the calculation of } \mathrm{CH}_{4} \\
\text { emissions from manure and housing } \\
\text { systems. }\end{array}$ & $\begin{array}{l}\text { Field: } \mathrm{N} \text { excreta related to energy needs and } \\
\text { diet quality, and } \mathrm{C}: \mathrm{N} \text { ratio of manure. Soil } \\
\text { temperature and humidity in a dynamic } \\
\text { equation. Barn: IPCC Tier } 2 \text { for } \mathrm{N}_{2} \mathrm{O} \text { from } \\
\text { manure and croplands. }\end{array}$ & OMD, OM, ME and N. \\
\hline $\begin{array}{l}\text { INRA Method (Eugène et } \\
\text { al., 2019) - France. }\end{array}$ & $\begin{array}{l}\text { Annual } \mathrm{CH}_{4} \mathrm{EF} \text { per animal based on VS } \\
\text { excretion (from indigested OM and urinary } \\
\mathrm{OM} \text {, and IPCC Tier 2), BO, MCF, and MS. } \\
\text { Annual manure EF per head: VS } \times \text { EC } \times 365 \text {. }\end{array}$ & $\begin{array}{l}\text { Eugène et al. (2019) does not describe } \mathrm{N}_{2} \mathrm{O} \\
\text { approach, but recommend estimations of } \\
\text { faecal and urinary } \mathrm{N} \text {, along with } \\
\text { determination of } \mathrm{OMD} \text { and } \mathrm{N} \text { digestibility. }\end{array}$ & OMD, OM, ME and N. \\
\hline $\begin{array}{l}\text { GAS-EM (Haenel et al., } \\
\text { 2020) - Germany. }\end{array}$ & $\begin{array}{l}\text { IPCC Tier 2: calculates annual } \mathrm{CH}_{4} \text { EF per } \\
\text { head of animal based on VS excretion, B0, } \\
\text { MCF, and MS. VS excretion for dairy cows } \\
\text { based on DMI, DOM and ash in feed. } \\
\text { Country specific values for MCF for different } \\
\text { manure storage systems. }\end{array}$ & $\begin{array}{l}\text { Type } 1+\text { with fixed } \mathrm{N}_{2} \mathrm{O} \text { and } \mathrm{NH}_{3} \mathrm{EF} \\
\text { disaggregated for different manure and } \\
\text { storage types and IPCC default for indirect } \\
\mathrm{N}_{2} \mathrm{O} \text { from } \mathrm{N} \text { leaching. }\end{array}$ & $\begin{array}{l}\mathrm{GE}, \mathrm{ME}, \mathrm{NEL}, \mathrm{OMD} \text {, ash and } \mathrm{N} \text { for key } \\
\text { livestock categories }\end{array}$ \\
\hline $\begin{array}{l}\text { The GHG model (O'Brien } \\
\text { et al., 2010) - Ireland. }\end{array}$ & $\begin{array}{l}\text { Type 1+ with fixed } \mathrm{CH}_{4} \mathrm{EF} \text { disaggregated for } \\
\text { storage (slurry, manure, silage effluent) or } \\
\text { soil applied (monthly slurry, manure). }\end{array}$ & $\begin{array}{l}\text { Type 1+ with fixed } \mathrm{N}_{2} \mathrm{O} \text { EF disaggregated for } \\
\text { storage (slurry, manure) or soil applied } \\
\text { (urine, faeces, slurry, manure), plus grazing } \\
\text { Nex. }\end{array}$ & Total DMI, OMD, and CP of the diet. \\
\hline $\begin{array}{l}\text { DairyWise (Schils et al., } \\
\text { 2007; Bannink et al., } \\
\text { 2020) - Netherlands. }\end{array}$ & $\begin{array}{l}\text { Type } 1+\text { with a fixed } \mathrm{CH}_{4} \mathrm{EF} \text { for manure } \\
\text { storage and one for manure applied to land. }\end{array}$ & $\begin{array}{l}\text { Type } 1+\text { with a fixed } \mathrm{N}_{2} \mathrm{O} \text { EF for stored } \\
\text { manure and } \mathrm{EF} \text { based on soil type and water } \\
\text { level for manure } \mathrm{N} \text { inputs to soil; and fixed } \\
\text { fractions for } \mathrm{N} \text { leaching and ammonia } \\
\text { volatilisation. }\end{array}$ & Total DMI, OMD, and CP of the diet. \\
\hline
\end{tabular}


Dairy Tier 3 (Bannink et

al., 2018) - Netherlands.

IPCC Tier 2: it calculates annual $\mathrm{CH}_{4} \mathrm{EF}$ per head of animal based on VS excretion, BO MCF, and MS. VS excretion based on OMD and VSD. Use of a Tier 3 is limited to the prediction of ND and urine $\mathrm{N}$ excretion (implemented), and OMD and VS excretion (currently not implemented).

OverseerFM (Wheeler et

al., 2008) - New Zealand. storage, application of stored manure to land, and faeces from grazing livestock. Based on proportion of faecal DM in each component and uses NZ inventory EF and IPCC Tier 2.

\section{Whole Farm Model}

(WFM) (Beukes et al.,

2010) - New Zealand

\begin{tabular}{ll}
\hline Arla Carbon tool, Arla & Emissions of $\mathrm{CH}_{4}$ from manure is calculated \\
Foods - Sweden. & based on IPCC (2006).
\end{tabular}
Does not estimate $\mathrm{CH}_{4}$ from manure, but it does estimate OMD.
IPCC Tier 2 with EF for urine, faeces and manure storage and land application. IPCC

Tier 3 for dairy cattle with prediction of Nex in urine based on $\mathrm{N}$ intake, apparent faecal $\mathrm{N}$ digestibility and $\mathrm{N}$ retention in animal product. $\mathrm{Nex}=\mathrm{N}$ intake $-\mathrm{N}$ retention for all other animal classes.

Estimates Nex based on DMl, dietary CP

and $\mathrm{N}$ in product; then splits between urine and faeces based on dietary N. Proportions urine and faeces to MMS and applies $\mathrm{N}_{2} \mathrm{O}$ EF from the NZ inventory.

Does not estimate $\mathrm{N}_{2} \mathrm{O}$ from manure, but it Total CP intake. does estimate $\mathrm{N}$ excretion in faeces and

urine $\left(\mathrm{g} \mathrm{N} \mathrm{d}^{-1}\right)$
Tier 2: total DMI, ME, OMD, and CP of the diet. Tier 3: DMI, aNDFom, starch, sugars, $\mathrm{CP}$, non-ammonia $\mathrm{CP}$, crude fat, ash, organic acids (for silages, lactic acid and VFA). In situ degradation of aNDFom, starch and CP

[washable $(\mathrm{W})$, potentially degradable (D) and rumen undegradable $(U)$ fraction, and fractional degradation rate $(k d)$ of $D]$.

Total DMI, OMD, ash, CP.

$\mathrm{N}_{2} \mathrm{O}$ emitted from manure based on the amount of $\mathrm{N}$ in excreta. Animal- $\mathrm{N}$ balance.

Total CP intake and VS, in addition to DM, Total $\mathrm{N}_{2} \mathrm{O}$ from manure systems calculated $\mathrm{CP}, \mathrm{CF}, \mathrm{FA}, \mathrm{DE}, \mathrm{NE}$. GE is calculated. as the sum of direct and indirect $\mathrm{N}_{2} \mathrm{O}$ emissions.

SIMSDAIRY (del Prado et $\mathrm{CH}_{4}$ from manure in storage based on IPCC al., 2011) - UK. $\mathrm{CH}_{4}$ from manure in storage based on IPCC,
and manure on land from country specific EF (per animal) derived from Chadwick and Pain (1997) and Yamulki et al. (1999) for applied manure and faeces from grazing.

\begin{tabular}{ll}
\hline Cool Farm Tool (Hillier et & IPCC Tier 2: calculates annual $\mathrm{CH}_{4} \mathrm{EF}$ per \\
al., 2011) - UK. & head of animal based on VS excretion, $\mathrm{B}_{0}$, \\
& MCF, and MS. Uses IPCC range of MMS and \\
& animal categories. Country-specific (rather \\
& than IPCC) EF for manure composting.
\end{tabular}

\section{Farmscoper (Gooday et IPCC Tier 2 (IPCC, 1996).}

al., 2014) - UK.

AgRE Calc - UK.

IPCC Tier 2: calculates annual $\mathrm{CH}_{4} \mathrm{EF}$ per head of animal based on VS excretion, $B_{0}$, $\mathrm{MCF}$, and MS.

$\mathrm{N}_{2} \mathrm{O}$ from manure storage from

Total DMI, OMD, ash, CP

EMEP/CORINAIR (2005). $\mathrm{N}_{2} \mathrm{O}$ from $\mathrm{Nex}$

deposited on soil estimated from mechanistic

approach (nitrification and denitrification).

Urinary and faecal $\mathrm{N}$ split based on dietary $\mathrm{N}$

IPCC Tier 2: calculates annual $\mathrm{N}_{2} \mathrm{O}$ from

MMS using IPCC N excretion rates for

'animal category by region'. Uses IPCC

range of MMS and animal categories.

Country-specific (rather than IPCC) EF for manure composting.

IPCC Tier 2 (IPCC, 1996) but with $\mathrm{NH}_{3}$ and $\mathrm{N}$ Total DMI, OMD, ash, CP.

leaching losses calculated in the model.

IPCC Tier 2: calculates annual $\mathrm{N}_{2} \mathrm{O}$ from Total DMI, OMD, ash, CP

manure based on livestock numbers,

Nex/head, MS, and $\mathrm{N}_{2} \mathrm{O}$ EF for each MMS.

Total DMI, OMD, ash, CP.

Abbreviations: B0: maximum $\mathrm{CH}_{4}$ producing capacity of manure; Faecal DM: faecal dry matter (estimated from DM

NoMD); FOM: fermentable organic matter;

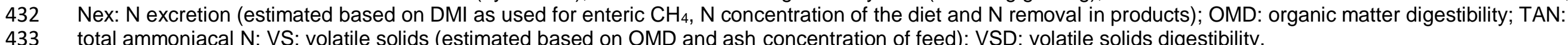

433 total ammoniacal N; VS: volatile solids (estimated based on OMD and ash concentration of feed); VSD: volatile solids digestibility. 


\section{Capturing the effects of diet on emissions from ruminant systems using} on-farm GHG models

\section{$6.1 \quad$ Opportunities}

Most prediction models of GHG emissions are based on feed (DM or GE) intake derived from feed evaluation systems applied in practice. Although these models consider the main driver of enteric $\mathrm{CH}_{4}$ emissions, they are inadequate to capture the effect of dietary chemical components and dietary chemical/physical characteristics on GHG emissions. As a result, these models cannot capture the effect of potential dietary GHG abatement options that alter diet characteristics such as lipid (Grainger and Beauchemin, 2011), fibre (Niu et al., 2018), and starch and sugar concentrations (Hindrichsen et al., 2005), ruminal and whole tract digestibility (Appuhamy et al., 2016), or secondary plant metabolites (Jayanegara et al., 2012; Sauvant et al., 2018). As a consequence, there is an increasing demand for models that take into account feed properties that both improve GHG prediction and can capture nutritional mitigation strategies (Niu et al., 2018; van Lingen et al., 2019; Benaouda et al., 2019).

A close examination of several enteric $\mathrm{CH}_{4}$ prediction equations for dairy cows used in on-farm GHG models showed that equations based on important aspects of diet composition performed better (i.e., having a greater accuracy) than those based on simpler, generic parameters or Type $1 / 2$ equations (Ellis et al., 2010). These findings are in agreement with the widely spread notion that enteric $\mathrm{CH}_{4}$ production is primarily driven by both amount and composition of feed consumed. More specifically, equations that included important aspects of diet composition, such as carbohydrate components [non-structural carbohydrates (NSC), hemicellulose (HC) 
and cellulose (Ce) (Moe and Tyrrell, 1979)] were more accurate in their predictions of enteric $\mathrm{CH}_{4}$ emissions compared with other equations (Ellis et al., 2010). The Moe and Tyrrell (1979) equation was used in an early version of the Molly model (Baldwin, 1995) to predict $\mathrm{CH}_{4}$ emissions (Palliser and Woodward, 2002). Ellis et al., (2010) examined other equations including those of Blaxter and Clapperton (1965) (also tested in Molly), Kirchgessner et al. (1995) used in FarmGHG, Giger-Reverdin et al. (2003) used in SIMSDAIRY, Corré (2002) used in Schils et al. (2005), Schils et al. (2006) used in DairyWise (recently updated based on Bannink et al., 2020), and a Type 1 (Tier 1) and a Type 2 (Tier 2) model from IPCC (1996), used in FarmSim and Phetteplace et al. (2001), respectively.

Due to the inclusion of diet composition information, the Moe and Tyrrell (1979) equation was the best performing in a direct comparison with other empirical equations (Ellis et al. 2010), as most of these equations did not include such information. Although the Moe and Tyrrell equation includes some important aspects of chemical composition (and an indirect estimate of feed intake level), other dietary characteristics that have proven effective in $\mathrm{CH}_{4}$ mitigation (i.e., lipid, starch and fibre concentration, OM digestibility; Dijkstra et al., 2010; Bannink et al., 2016), are not. Furthermore, the equation assumes a constant $\mathrm{CH}_{4}$ yield per unit of $\mathrm{NSC}, \mathrm{HC}$ and Ce, as discussed in Ellis et al. (2008). The implications of this assumption is that it excludes differential ruminal fermentability and passage rate of these components associated with variations in feed intake level, in turn affecting efficiency of microbial synthesis, VFA production, ruminal $\mathrm{pH}$, VFA profile and $\mathrm{CH}_{4}$ production (Hindrichsen et al., 2005; Dijkstra et al., 2010). Overall, the use of fixed $\mathrm{CH}_{4}$ conversion factors led to low $\mathrm{CH}_{4}$ prediction accuracy and imposes severe limits to opportunities for nutritional mitigation of GHG emissions (Ellis et al., 2010). Consistent with these 
483 findings, Jentsch et al. (2007) concluded that a major component of $\mathrm{CH}_{4}$ production could not be explained solely by DMI. Consideration of all digestible nutrients in the diet revealed that the carbohydrate fraction, particularly digestible (crude) fibre and digestible $\mathrm{N}$-free residuals contributed the most to $\mathrm{CH}_{4}$ production, whereas digestible fat had an inhibitory effect (Jentsch et al., 2007).

More recently, Niu et al. (2018) identified the main predictor variables of dairy $\mathrm{CH}_{4}$ production $\left(\mathrm{g} \mathrm{CH}_{4} \mathrm{cow}^{-1}\right.$ day $\left.^{-1}\right)$, and examined the trade-offs between the availability of input variables (including diet characteristics) and the accuracy of models (assessed with several measures of model predictive ability) using the large dairy $\mathrm{CH}_{4}$ database from the international collaborative initiative GLOBAL NETWORK (https://globalresearchalliance.org/research/livestock/collaborative-activities/globalresearch-project/). Along with records of enteric $\mathrm{CH}_{4}$ production, milk yield, milk composition and BW, the database includes dietary concentrations of GE, CP, EE, NDF, ash and measured (or estimated) DMI. In addition to supporting the wellestablished notion that $\mathrm{DMI}$ is the most important variable to predict $\mathrm{CH}_{4}$ production from dairy cows, the inclusion of diet characteristics such as NDF and EE concentration improved the accuracy of prediction of enteric $\mathrm{CH}_{4}$ production (Ramin and Huhtanen, 2013; Niu et al., 2018).

The GLOBAL NETWORK project data were also used by Benaouda et al. (2019) to examine the predictive ability of existing enteric $\mathrm{CH}_{4}$ equations compared with measurements obtained from calorimetry chambers, the $\mathrm{SF}_{6}$ tracer technique and automated head chambers across ruminant species. Enteric $\mathrm{CH}_{4}$ emissions $(\mathrm{g} \mathrm{CH}$ $\mathrm{d}^{-1}$ ) from dairy cattle were suitably predicted by equations that included feed intake 506 (DMI, GEI) and/or feed level (DMI/BW) as predictors (Mills et al., 2003; Ramin and 
Huhtanen, 2013; Charmley et al., 2016). However, the best performing equation

508 (Ramin and Huhtanen, 2013) included GE digestibility and lipid concentration (EE), in addition to feeding level (Benaouda et al., 2019). Although most equations that include digestibility use digestible OM rather than digestible GE, both variables have been well established predictors of enteric $\mathrm{CH}_{4}$ emissions (Blaxter and Clapperton, 1965; Sauvant and Nozière, 2016).

513 Ellis et al. (2010) showed that the accuracy of enteric $\mathrm{CH}_{4}$ predictions using a fixed $\mathrm{CH}_{4}$ energy conversion factor was low. In addition to limiting the possibility of implementing nutritional mitigation strategies (as mentioned above), the use of such

516 fixed conversion factors can potentially introduce substantial error at the farm scale.

517 These errors can escalate at larger scales (e.g. in GHG inventories) and may lead to unsuitable mitigation recommendations or inaccurate projections of $\mathrm{CH}_{4}$ emissions over time (Bannink et al., 2011).

520 The effect of dietary strategies on $\mathrm{N}_{2} \mathrm{O}$ emissions are largely driven by total $\mathrm{N}$ intake, or more importantly, the total $\mathrm{N}$ output in excreta or manure. Dietary $\mathrm{N}$ concentration is therefore a key parameter that needs to be captured, as is the case in most onfarm GHG models. In addition, the partitioning of $\mathrm{N}$ between urine and faeces affects $\mathrm{N}_{2} \mathrm{O}$ emissions, as it is well-accepted that $\mathrm{N}_{2} \mathrm{O}$ emissions from urine are greater than those from faeces (IPCC, 2019). Diet characteristics that affect $\mathrm{N}$ partitioning in urine and faeces include, amongst others, DMI, $\mathrm{N}$ intake, rumen-fermentable OM leading

527 to the synthesis of microbial N, DM digestibility, CP concentration, and the presence of secondary metabolites such as tannins. Dry matter digestibility and CP are negatively related to $\mathrm{N}$ partitioning in faeces, whereas tannin concentration is 530 positively related to the proportion of $\mathrm{N}$ excreted as faecal $\mathrm{N}$ (de Klein and Eckard, 
531 2008; Sauvant et al., 2014). All the on-farm GHG models reviewed in this paper 532 capture DMI, dietary DMD and CP (or N) concentration, but very few (if any) take account of more detailed aspects such as the effect of differing profiles of $\mathrm{N}$ disappearance (ruminal and whole-tract) or the concentration of plant secondary metabolites such as tannins in the diet.

In a meta-analysis by Sauvant et al. (2014), relationships between $\mathrm{CH}_{4}$ and urinary outputs were derived for ruminants fed forages (temperate and tropical forages) as their sole diet. It was shown that $\mathrm{CH}_{4}$ production was closely related to digestible $\mathrm{OM}$ intake when both variables were expressed per unit of DMI or LW. This suggests that digestible OM intake is a key parameter to be captured in models for estimating $\mathrm{CH}_{4}$ emissions from forage-fed ruminants. In agreement with these findings, Warner et al. (2017) reported that enteric $\mathrm{CH}_{4}$ methane emissions were clearly affected by grass silage quality (based on harvesting leafy to late-heading grass maturity stages), more so than by DMI level (based on stage of lactation). Per unit of OM or NDF digested, $\mathrm{CH}_{4}$ yields were similar between DMI levels, but noticeable increases were seen when reported on a digestible OM intake basis (Warner et al., 2017).

547 Sauvant et al. (2014) also showed that, when animals are managed indoors with an anaerobic slurry storage, mitigation of enteric $\mathrm{CH}_{4}$ appeared to be partly offset by a higher production of $\mathrm{CH}_{4}$ from manure.

550 The use of dynamic mechanistic modelling in the simulation of enteric $\mathrm{CH}_{4}$ emissions and $\mathrm{N}_{2} \mathrm{O}$ emissions from animal excreta, has resulted in more accurate predictions than simple regression equations (Benchaar et al., 1998). Although the INRA/IPCC (2006) ratio for enteric $\mathrm{CH}_{4}$ emissions was close to unity and estimates did not differ between models for adult cows (i.e., most cattle in France), the use of dietary 
characteristics such as digestible OM intake (corrected for feeding level and proportion of concentrate in the diet) in the prediction allows for different mitigation strategies to be tested (Sauvant et al., 2018; Eugène et al., 2019). Furthermore, mechanistic modelling of methanogenesis in particular, has allowed for IPCC Tier 3 approaches to go beyond the farm scale (Bannink et al., 2011; Huhtanen et al., 2015). In addition, the use of a country-specific (i.e., Dutch studies only) Tier 3 approach to predict faecal $\mathrm{N}$ digestibility (Bannink et al., 2018) resulted in more accurate predictions than using feeding tables (CVB model; CVB, 2011), in particular for Dutch studies for which more accurate estimates of model inputs on rumen degradability of substrates were available. The over-prediction of the CVB model would lead to an over-prediction of urine or ammoniacal $\mathrm{N}$ excretion, in turn leading to biased estimations of the $\mathrm{N}$ mitigation potential from nutritional strategies (Bannink et al., 2018).

\subsection{Challenges}

Overall, on-farm models that predict enteric $\mathrm{CH}_{4}$ emissions are based on a few animal and feed characteristics, but DMI is typically the key parameter to consider. Analyses of large datasets of individual dairy cows have shown that simplified equations based on DMl alone or in combination with a few feed and/or animal related variables can predict mean enteric $\mathrm{CH}_{4}$ emissions with a similar accuracy to that of more detailed empirical equations (Hristov et al., 2018; Niu et al., 2018). Although reliable for national emission inventory purposes, these approaches do not allow for exploring nutritional mitigation options on specific farms.

Accurate predictions of DMI are essential to achieve accurate predictions of livestock emissions, including enteric and manure $\mathrm{CH}_{4}$, and $\mathrm{N}_{2} \mathrm{O}$ emissions. In some 
confinement-type feeding systems where predictions of DMI can rely on robust and frequently-updated feed evaluation systems, the issue of prediction accuracy becomes of less concern. For example, using data from North America, model equations that used estimates of DMI could predict enteric $\mathrm{CH}_{4}$ emissions as accurately as when using measured DMI data, provided DMI could be estimated with reasonable accuracy (Appuhamy et al., 2016), and prediction accuracy was not improved by further addition of diet characteristics to the model (Niu et al., 2018). Using European data, estimates rather than measured DMI provided for acceptable predictions (RMSPE $\leq 15 \%$; CCC $\geq 0.50$ ), whereas using estimates of DMI for Australia and New Zealand provided for poor predictive performance of enteric $\mathrm{CH}_{4}$ emissions (RMSPE > 25\%; CCC < 0.40) (Appuhamy et al., 2016). The differences in accuracy were most likely attributed to the DMI prediction models used, based on North American data that are unlikely to address diets with a high proportion of forage (Appuhamy et al., 2016; Hristov et al., 2018). As expected, forages (offered either fresh or conserved) dominated the diets used in Australia and New Zealand (mean values of $88 \%$ vs. $52 \%$ and $64 \%$ for North American and European diets, respectively). Obtaining reasonable estimates of herbage DMI in a grazing situation can be challenging, as results obtained from different methods (e.g., the use of markers, herbage disappearance and inferences from animal performance) can vary substantially and can potentially be misleading (Macoon et al., 2003).

The type of livestock farming system is also an important consideration when assessing the value of refining on-farm GHG models to capture more details concerning dietary strategies. In fully housed livestock systems, where animals are fed a total mixed ration for example, dietary measures to reduce GHG emissions can be more easily adopted compared with systems that rely on grazing-based diets to 
604

varying degrees. In reality, it is highly unlikely that one feed constituent (e.g., NDF concentration) will vary while others remain unchanged, due to the inherent association between diet constituents in diet formulation, but any goal-directed change is easier to achieve in confinement-type diets or through supplemental feeding than in grazing situations. The latter also offer dynamic changes (seasonal, daily, hourly) in herbage quantity, composition, nutritive value, and animal preference, which add complexity to DMI predictions from pasture-based systems.

Recently, Niu et al. (2018) highlighted the potential effects of increased intake and associated effects such as increased passage rate and reduced time for ruminal digesta retention, which in turn can reduce $\mathrm{OM}$ digestibility and $\mathrm{CH}_{4}$ production per unit of feed (i.e., a reduction in $\mathrm{g} \mathrm{CH}_{4} \mathrm{~kg}^{-1} \mathrm{DMI}$ ) (Van Soest, 1994). Feed intake is a consequence of feed on offer, animal production demand and digestibility of nutrients. In contrast with Type 3 models where the effect is captured, Type 2 models do not account for the effect of changes in feeding level, often expressed as multipliers of maintenance energy levels (e.g., NRC, 2001).

Another challenge for on-farm GHG models to capture dietary strategies is the accuracy and availability of input data to run the models. Availability of data and transparency in the description and adoption of methodological procedures are essential to make informed decisions on GHG abatement strategies, and even more so when these tools are to inform policy (Hall et al., 2010). The more detailed the model in terms of inclusion of dietary characteristics, the higher the level of detail that is required for the input and activity data. This not only includes detail on diet composition (e.g., proportions of different feed types), but also on diet characteristics within each ration ingredient or feed type. In many cases, the complexity of obtaining 
or recording additional input data needs to be carefully balanced against the benefit of being able to capture the effect of a given dietary strategy in the model.

Nevertheless, in many cases of intensive farming systems, reasonable estimates or feed table values can be used as inputs, or obtained from commercial lab 'highthroughput' analysis of nutritional value (e.g. Near Infra-Red Spectroscopy). These estimates or feed table values can be more generic than detailed measurements as an input, but they still offer potential to capture more of the variation in GHG emissions, as these estimates are based on variation in feed chemical composition.

Empirical models that include commonly measured dietary inputs can be fairly successful in predicting $\mathrm{CH}_{4}$ emissions (Ellis et al., 2007). However, the impact of mitigation strategies to reduce $\mathrm{CH}_{4}$ emissions needs to be assessed in a more integrated way, and often empirical models do not have the biological basis for such assessment. Mathematical models of fermentation and digestion have become extremely useful to simulate the complex digestive processes in the rumen, to increase our understanding of the complexity of systems and to identify areas where knowledge is lacking and more research is required to improve both understanding and accuracy of predictions (Ellis et al., 2008). Dynamic components of $\mathrm{CH}_{4}$ predictions have been added to these mechanistic models (e.g., Benchaar et al. 1998; Mills et al. 2001) and delivered improved prediction of the effect of specific mitigation measures. However, limitations in the accuracy of $\mathrm{CH}_{4}$ predictions continue to surface (Bannink et al., 2016). Earlier work in search for causes of inaccurate simulation of rumen function (leading to inaccurate predictions of enteric $\mathrm{CH}_{4}$ ) already identified the need for accurate estimates of stoichiometry of VFA production with substrate fermentation and VFA absorption kinetics (Bannink et al., 1997) and interspecies $\mathrm{H}_{2}$ transfer (Ellis et al., 2008). 
653 Finally, it is important to note that most of the models available (and those selected

654 in this review) have been developed for temperate conditions and related animal

655

656

657

658

659

660

661

662

663

664

665

666

667

668

669

670

671

672

673

674

675

676 breeds and feed nutritive values, often involving adult Holstein-Friesian and Jersey cattle with ad libitum access to feed and quality drinking water (i.e., low nitrate concentrations) under European and New Zealand conditions. Models have been developed for diets or dietary ingredients with a common mineral, DM and OM concentration including typical grass / legume mixed pastures (fresh and conserved), maize (grain and silage), other grains, concentrates and by-products, with feed nutritive values described in various feed tables. Development and evaluation of models for livestock production systems in arid and tropical regions is extremely limited to date, highlighting the need for greater effort by the international research community in this area.

\section{Conclusions}

The models reviewed in this paper generally include Type 2 or combinations of Type 2 and Type 3 approaches depending on livestock class, GHG considered and emissions source involved. The majority of enteric $\mathrm{CH}_{4}$ models use a Type 2 approach to estimate DMI from production data and animal population characteristics, whereas a limited number of models use the more detailed mechanistic Type 3 approach. Type 2 models can capture a varying range of diet characteristics, including total DMI, DM or OM digestibility, ME/GE, and CP concentration. Most models then use a $\mathrm{CH}_{4} \mathrm{EF}\left(\mathrm{g} \mathrm{CH}_{4} \mathrm{~kg}^{-1} \mathrm{DMI}\right)$ and a $\mathrm{N}_{2} \mathrm{O} \mathrm{EF}$ ( $\mathrm{N}_{2} \mathrm{O}-\mathrm{N}$ emitted as \% of $\mathrm{N}$ excreted) to estimate $\mathrm{GHG}$ emissions. Some models include different $\mathrm{CH}_{4} \mathrm{EF}$ for different diets or dietary ingredients (e.g., DairyWise, with $\mathrm{EF}$ values derived from a Type 3 approach) rather than $\mathrm{CH}_{4} \mathrm{EF}$ purely based on 
677 animal species (e.g., OverseerFM). Only Type 3 models represent underlying

678 mechanisms such as ruminal fermentation and total-tract digestive processes (e.g.,

679 Karoline, Dairy Tier 3, Whole Farm Model). Prior to a proper representation of these

680 processes, ruminal digestibility of, and competition for, different substrates, bypass

681 fractions, and the rate (faster fermentation, lesser $\mathrm{CH}_{4}$ production) and extent of

682 fermentation, along with adequate descriptions of OM chemical composition, need to

683 be captured by these models. Other aspects such as the effect of secondary

684 metabolites on $\mathrm{CH}_{4}$ EF also need to become apparent.

685 There are opportunities for all models to improve their ability to capture dietary

686 mitigation strategies, but the value of doing so should be carefully balanced against

687 gains in accuracy of the estimates, the need for additional input and activity data, the

688 variability actually encountered on-farm and among farms, and the need for

689 consistency between different approaches that are to be used for different purposes

690 (inventory vs. on-farm accounting vs. life cycle analysis).

691

8. Acknowledgements

692 This review was funded by: the New Zealand Government, in support of the objectives of the Livestock Research Group of the Global Research Alliance on Agricultural Greenhouse Gases (GRA; S7-SOW16-ERAGAS-CEDERS); the Ministry of Agriculture, Nature and Food Quality, The Netherlands (PPS project AF-EU18010) and The Netherlands Organisation for Scientific Research (ALW.GAS.2); Ministry of Agriculture and Forestry, Finland; The Secretary of State for Environment, 698 Food and Rural Affairs, UK; French National Research Agency, France; Federal 699 Ministry of Food and Agriculture, Germany; TEAGASC and Department of 
Agriculture, Food and the Marine, Ireland; Innovation fund, Denmark; Research

Council for Environment, Areal Industries and Community Development, Sweden.

\section{References}

Appuhamy, J.A.D.R.N., France, J., Kebreab, E., 2016. Models for predicting enteric methane emissions from dairy cows in North America, Europe, and Australia and New Zealand. Global Change Biology 22, 3039-3056.

Baldwin, R.L., 1995. Modeling ruminant digestion and metabolism Chapman \& Hall, London, UK.

Bannink, A., De Visser, H., Klop, A., Dijkstra, J., France, J., 1997. Causes of inaccurate prediction of volatile fatty acids by simulation models of rumen function in lactating cows. Journal of Theoretical Biology 189, 353-366.

Bannink, A., Spek, W.J., Dijkstra, J., Šebek, L.B.J., 2018. A Tier 3 method for enteric methane in dairy cows applied for fecal $\mathrm{N}$ digestibility in the ammonia inventory. Frontiers in Sustainable Food Systems 2, 66.

Bannink, A., van Lingen, H.J., Ellis, J.L., France, J., Dijkstra, J., 2016. The contribution of mathematical modeling to understanding dynamic aspects of rumen metabolism. Frontiers in Microbiology 7, 1820.

Bannink, A., van Schijndel, M.W., Dijkstra, J., 2011. A model of enteric fermentation in dairy cows to estimate methane emission for the Dutch National Inventory Report using the IPCC Tier 3 approach. Animal Feed Science \& Technology 166-167, 603-618.

Bannink, A., Zom, R.L.G., Groenestein, K.C., Dijkstra, J., Sebek, L.B.J., 2020. Applying a mechanistic fermentation and digestion model for dairy cows with emission and nutrient cycling inventory and accounting methodology. Animal 14:S2, s406-s416.

Beauchemin, K.A., Kreuzer, M., O'Mara, F., McAllister, T.A., 2008. Nutritional management for enteric methane abatement: a review. Australian Journal of Experimental Agriculture 48, 21-27.

Benaouda, M., Martin, C., Li, X., Kebreab, E., Hristov, A.N., Yu, Z., Yáñez-Ruiz, D.R., Reynolds, C.K., Crompton, L.A., Dijkstra, J., Bannink, A., Schwarm, A., Kreuzer, M., McGee, M., Lund, P., Hellwing, A.L.F., Weisbjerg, M.R., Moate, P.J., Bayat, A.R., Shingfield, K.J., Peiren, N., Eugène, M., 2019. Evaluation of the performance of existing mathematical models predicting enteric methane emissions from ruminants: Animal categories and dietary mitigation strategies. Animal Feed Science \& Technology 255, 114207.

Benchaar, C., Pomar, C., Chiquette, J., 2001. Evaluation of dietary strategies to reduce methane production in ruminants: A modelling approach. Canadian Journal of Animal Science 81, 563-574. 
Benchaar, C., Rivest, J., Pomar, C., Chiquette, J., 1998. Prediction of methane production from dairy cows using existing mechanistic models and regression equations. Journal of Animal Science 76, 617-627.

Beukes, P.C., Gregorini, P., Romera, A.J., 2011. Estimating greenhouse gas emissions from New Zealand dairy systems using a mechanistic whole farm model and inventory methodology. Animal Feed Science \& Technology 166, 708-720.

Beukes, P.C., Gregorini, P., Romera, A.J., Levy, G., Waghorn, G.C., 2010. Improving production efficiency as a strategy to mitigate greenhouse gas emissions on pastoral dairy farms in New Zealand. Agriculture, Ecosystems and Environment 136, 358-365.

Beyer, M., Chudy, A., Hoffmann, L., Jentsch, W., Laube, W., Nehring, K., Schiemann, R., 2003. Rostock feed evaluation system: reference numbers of feed value and requirement on the base of net energy. Plexus-Verlag, Miltenberg.

Blaxter, K.L., Clapperton, J.L., 1965. Prediction of the amount of methane produced by ruminants. British Journal of Nutrition 19, 511-521.

Blok, M.C., Spek, J.W., 2016. CVB Veevoedertabel 2016 : chemische samenstellingen en nutritionele waarden van voedermiddelen. CVB, Netherlands. Available at: https://edepot.wur.nl/379631.

Brown, L., Jarvis, S.C., Headon, D., 2001. A farm-scale basis for predicting nitrous oxide emissions from dairy farms. Nutrient Cycling in Agroecosystems 60, 149-158.

Caro, D., Kebreab, E., Mitloehner, F.M., 2016. Mitigation of enteric methane emissions from global livestock systems through nutrition strategies. Climate Change 137, 467-480.

Chadwick, D.R., Cardenas, L.M., Dhanoa, M.S., Donovan, N., Misselbrook, T., Williams, J.R., Thorman, R.E., McGeough, K.L., Watson, C.J., Bell, M., Anthony, S.G., Rees, R.M., 2018. The contribution of cattle urine and dung to nitrous oxide emissions: Quantification of country specific emission factors and implications for national inventories. Science of the Total Environment 635, 607-617.

Chadwick, D.R., Pain, B.F., 1997. Methane fluxes following slurry applications to grassland soils: laboratory experiments. Agriculture, Ecosystems and Environment 63, 51-60.

Charmley, E., Williams, S.R.O., Moate, P.J., Hegarty, R.S., Herd, R.M., Oddy, V.H., Reyenga, P., Staunton, K.M., Anderson, A., Hannah, M.C., 2016. A universal equation to predict methane production of forage-fed cattle in Australia. Animal Production Science $56,169-180$.

Colomb, V., Bernoux, M., Bockel, L., Chotte, J.-L., Martin, S., Martin-Phipps, C., Mousset, J., Tinlot, M., Touchemoulin, O., 2012. Review of GHG calculators in agriculture and forestry sectors. A guideline for appropriate choice and use of landscape based tools. FAO EXACT team (EX-Ante Carbon-balance tool - www.fao.org/tc/exact), The Joint Research Unit Eco\&Sols (Functional Ecology and Biogeochemistry of Soils \& Agro-ecosystems http://www.montpellier.inra.fr/ecosols) and the ADEME ClimAgri programme (www.ademe.fr).

Corré, W.J., 2002. Agricultural Land Use and Emissions of Methane and Nitrous Oxide in Europe. Report 40, Plant Research International, Wageningen, the Netherlands. 29 pp. 
Cowie, A., Eckard, R., Eady, S., 2012. Greenhouse gas accounting for inventory, emissions trading and life cycle assessment in the land-based sector: a review. Crop \& Pasture Science 63, 284-296.

CSIRO, 2007. Nutrient Requirements of Domesticated Ruminants. CSIRO Publishing, Victoria, Australia.

CVB, 2011. Table of Feedstuffs: Information about Composition, Digestibility, and Feeding Values. The Hague: Centraal Veevoederbureau, Product Board Animal Feed.

Danfær, A., Huhtanen, P., Uden, P., Sveinbjornsson, J., Volden, H., 2006. The Nordic dairy cow model, Karoline - description. In: Kebreab, E., Dijkstra, J., Bannink, A., Gerrits, W.J., France, J. (Eds.), Nutrient digestion and utilization in farm animals: modelling approaches. CABI Publishing, Wallingford, pp. 383-406.

de Klein, C.A.M., Eckard, R.J., 2008. Targeted technologies for nitrous oxide abatement from animal agriculture. Australian Journal of Experimental Agriculture 48, 14-20.

de Klein, C.A.M., Ledgard, S.F., 2005. Nitrous oxide emissions from New Zealand agriculture - key sources and mitigation strategies. Nutrient Cycling in Agroecosystems 72, 77-85.

de Klein, C.A.M., Rollo, M., van der Weerden, T.J. 2019. Assessment of tools for estimating on-farm GHG emissions - final report. Report for the Ministry for Primary Industries, Wellington, New Zealand. 29 Pages. https://www.mpi.govt.nz/dmsdocument/39092assessment-of-tools-for-estimating-on-farm-ghg-emissions-pdf

del Prado, A., Misselbrook, T., Chadwick, D., Hopkins, A., Dewhurst, R.J., Davison, P., Butler, A., Schröder, J., Scholefield, D., 2011. SIMSDAIRY: A modelling framework to identify sustainable dairy farms in the UK. Framework description and test for organic systems and $\mathrm{N}$ fertiliser optimisation. Science of the Total Environment 409, 3993-4009.

Denef, K., Paustian, K., Archibeque, S., Biggar, S., Pape, D., 2012. Report of Greenhouse Gas Accounting Tools for Agriculture and Forestry Sectors. Interim report to USDA under Contract No. GS23F8182H.

Dijkstra, J., France, J., Ellis, J.L., Kebreab, E., Lopez, S., Reijs, J.W., Bannink, A., 2010. Effects of nutritional strategies on simulated nitrogen excretion and methane emission in dairy cattle. Modelling Nutrient Digestion and Utilisation in Farm Animals, pp. 394-402.

Dijkstra, J., Neal, H.D.S.C., Beever, D.E., France, J., 1992. Simulation of nutrient digestion, absorption and outflow in the rumen: model description. Journal of Nutrition 122, 2239 2256.

Ellis, J.L., Bannink, A., France, J., Kebreab, E., Dijkstra, J., 2010. Evaluation of enteric methane prediction equations for dairy cows used in whole farm models. Global Change Biol. 16, 3246-3256.

Ellis, J.L., Dijkstra, J., Kebreab, E., Bannink, A., Odongo, N.E., McBride, B.W., France, J., 2008. Aspects of rumen microbiology central to mechanistic modelling of methane production in cattle. Journal of Agricultural Science 146, 213-233. 
Ellis, J.L., Kebreab, E., Odongo, N.E., McBride, B.W., Okine, E.K., France, J., 2007. Prediction of methane production from dairy and beef cattle. Journal of Dairy Science 90 , 3456-3466.

Elsgaard, L., Olsen, A.B., Petersen, S.O., 2016. Temperature response of methane production in liquid manures and co-digestates. Science of the Total Environment 539, 78-84.

EMEP/EEA. 2016. EMEP/EEA air pollutant emission inventory Guidebook 2016. 3.B Manure management. Copenhagen, European Environment Agency. EEA Report No 21/2016.

EMEP/CORINAIR, 2005. Emission inventory guidebook, fourth ed. Copenhagen, Denmark: European Environment Agency.

Eugène, M., Sauvant, D., Nozière, P., Viallard, D., Oueslati, K., Lherm, M., Mathias, E., Doreau, M., 2019. A new Tier 3 method to calculate methane emission inventory for ruminants. Journal of Environmental Management 231, 982-988.

Fox, D.G., Tedeschi, L.O., Tylutki, T.P., Russell, J.B., Van Amburgh, M.E., Chase, L.E., Pell, A.N., Overton, T.R., 2004. The Cornell Net Carbohydrate and Protein System model for evaluating herd nutrition and nutrient excretion. Animal Feed Science \& Technology 112, 29-78.

Giger-Reverdin, S., Morand-Fehr, P., Tran, G., 2003. Literature survey of the influence of dietary fat composition on methane production in dairy cattle. Livestock Production Science 82, 73-79.

Gooday, R.D., Anthony, S.G., Chadwick, D.R., Newell-Price, P., Harris, D., Duethmann, D., Fish, R., Collins, A.L., Winter, M., 2014. Modelling the cost-effectiveness of mitigation methods for multiple pollutants at farm scale. Science of the Total Environment 468-469, 1198-1209.

Grainger, C., Beauchemin, K.A., 2011. Can enteric methane emissions from ruminants be lowered without lowering their production? Animal Feed Science \& Technology 166-167, 308-320.

Graux, A.I., Gaurut, M., Agabriel, J., Baumont, R., Delagarde, R., Delaby, L., Soussana, J.F., 2011. Development of the Pasture Simulation Model for assessing livestock production under climate change. Agriculture, Ecosystems and Environment 144, 69-91.

Grönroos, J., J. Munther and S. Luostarinen. 2017. Calculation of atmospheric nitrogen and NMVOC emissions from Finnish Agriculture - Description of the revised model, Reports of the Finnish environment institute 37, ISBN 978-952-11-4902-3.

Haenel, H.-D., Rösemann, C., Dämmgen, U., Döring, U., Wulf, S., Eurich-Menden, B., Freibauer, A., Döhler, H., Schreiner, C., Osterburg, B., Fuß, R., 2020. Calculations of gaseous and particulate emissions from German agriculture 1990 - 2018: Report on methods and data (RMD) Submission 2020. Braunschweig: Johann Heinrich von ThünenInsti tut, 448 p, Thünen Rep 77, DOI:10.3220/REP1584363708000.

Hall, P., Holmes-Ling, P., Stewart, K., Sheane, R., 2010. A Scottish farm-based greenhouse gas accounting tool. A review of existing tools and recommendations for improved emissions accounting and reporting within agriculture and horticulture. Prepared by 
Laurence Gould Partnership Ltd. and Best Foot Forward for the Scottish Government. Edinburgh, Scotland.

Hellwing, A.L.F., Weisbjerg, M.R., Brask, M., Alstrup, L., Johansen, M., Hymøller, L., Larsen, M.K., Lund, P., 2016. Prediction of the methane conversion factor $\left(Y_{m}\right)$ for dairy cows on the basis of national farm data. Animal Production Science 56, 535-540.

Henderson, G., Cox, F., Ganesh, S., et al., 2015. Rumen microbial community composition varies with diet and host, but a core microbiome is found across a wide geographical range. Scientific Reports 5, 14567. https://doi.org/10.1038/srep14567

Hillier, J., Walter, C., Malin, D., Garcia-Suarez, T., Mila-i-Canals, L., Smith, P., 2011. A farmfocused calculator for emissions from crop and livestock production. Environmental Modelling and Software 26, 1070-1078.

Hindrichsen, I.K., Wettstein, H.R., Machmüller, A., Jörg, B., Kreuzer, M., 2005. Effect of the carbohydrate composition of feed concentrates on methane emission from dairy cows and their slurry. Environmental Monitoring and Assessment 107, 329-350.

Hristov, A.N., Kebreab, E., Niu, M., Oh, J., Bannink, A., Bayat, A.R., Boland, T.M., Brito, A.F., Casper, D.P., Crompton, L.A., Dijkstra, J., Eugène, M., Garnsworthy, P.C., Haque, N., Hellwing, A.L.F., Huhtanen, P., Kreuzer, M., Kuhla, B., Lund, P., Madsen, J., Martin, C., Moate, P.J., Muetzel, S., Muñoz, C., Peiren, N., Powell, J.M., Reynolds, C.K., Schwarm, A., Shingfield, K.J., Storlien, T.M., Weisbjerg, M.R., Yáñez-Ruiz, D.R., Yu, Z., 2018. Symposium review: Uncertainties in enteric methane inventories, measurement techniques, and prediction models. Journal of Dairy Science 101, 6655-6674.

Huhtanen, P., Ramin, M., Udén, P., 2015. Nordic dairy cow model Karoline in predicting methane emissions: 1. Model description and sensitivity analysis. Livestock Science 178, 71-80.

Illius, A.W., Gordon, I.J., 1991. Prediction of intake and digestion in ruminants by a model of rumen kinetics integrating animal size and plant characteristics. The Journal of Agricultural Science 116, 145-157.

INRA, 2018. INRA Feeding System for Ruminants. NLD: Wageningen Academic Publishers, $640 \mathrm{p}$.

IPCC, 2006. Chapter 10 Emissions from Livestock and Manure Management. In 2006 IPCC Guidelines for National Greenhouse Gas Inventories, Vol 4. Agriculture, Forestry and Other Land Use, Prepared by the National Greenhouse Gas Inventories Programme. In: Eggleston, S., Buendia, L., Miwa, K., Ngara, T., Tanabe, K. (Eds.), Japan: IGES. http://www.ipcc-nggip.iges.or.jp/public/2006gl/vol4.html.

IPCC, 2019. Refinement to the 2006 IPCC Guidelines for National Greenhouse Gas Inventories. Available at: https://www.ipccnggip.iges.or.jp/public/2019rf/pdf/4 Volume4/19R V4 Ch11 Soils N2O CO2.pdf

IPCC, 1996. Revised 1996 IPCC Guidelines for National Greenhouse Gas Inventories. Greenhouse Gas Inventory Reference Manual. Volume 3. Hadley Centre, Bracknell, UK. 
Jaurena, G., Cantet, J.M., Arroquy, J.I., Palladino, R.A., Wawrzkiewicz, M., Colombatto, D., 2015. Prediction of the Ym factor for livestock from on-farm accessible data. Livestock Science 177, 52-62.

Jayanegara, A., Leiber, F., Kreuzer, M., 2012. Meta-analysis of the relationship between dietary tannin level and methane formation in ruminants from in vivo and in vitro experiments. Journal of Animal Physiology and Animal Nutrition 96, 365-375.

Jentsch, W., Schweigel, M., Weissbach, F., Scholze, H., Pitroff, W., Derno, M., 2007. Methane production in cattle calculated by the nutrient composition of the diet. Archives of Animal Nutrition 61, 10-19.

Kirchgessner, M., Windisch, W., Muller, H.L., 1994. Methane release from dairy cows and pigs. In: Aguilera, J.F. (Ed.), Proceedings of the $8^{\text {th }}$ Symposium on energy metabolism of farm animals. EAAP Publication No. 76, pp. 399-402.

Kirchgessner, M., Windisch, W., Müller, H.L., 1995. Nutritional factors for the quantification of methane production. In: Engelhardt, W.V., Leonhard-Marek, S., Breves, G., Giesecke, D. (Eds.), Ruminant physiology: digestion, metabolism, growth and reproduction. Proceedings of the Eighth International Symposium on Ruminant Physiology, Ferdinand Enke Verlag: Stuttgart, Germany, pp. 333-348.

Macoon, B., Sollenberger, L.E., Moore, J.E., Staples, C.R., Fike, J.H., Portier, K.M., 2003. Comparison of three techniques for estimating the forage intake of lactating dairy cows on pasture. Journal of Animal Science 81, 2357-2366.

Martin, C., Morgavi, D. P., Doreau, M., 2010. Methane mitigation in ruminants: from microbe to the farm scale. Animal, 4, 351-365. https://doi.org/10.1017/S1751731109990620.

Mills, J.A.N., Dijkstra, J., Bannink, A., Cammell, S.B., Kebreab, E., France, J., 2001. A mechanistic model of whole-tract digestion and methanogenesis in the lactating dairy cow: Model development, evaluation, and application. Journal of Animal Science 79, 1584-1597.

Mills, J.A.N., Kebreab, E., Yates, C.M., Crompton, L.A., Cammell, S.B., Dhanoa, M.S., Agnew, R.E., France, J., 2003. Alternative approaches to predicting methane emissions from dairy cows. Journal of Animal Science 81, 3141-3150.

Milne, E., Neufeldt, H., Rosenstock, T., Smalligan, M., Cerri, C.E., Malin, D., Easter, M., Bernoux, M., Ogle, S., Casarim, F., Pearson, T., Bird, D.N., Steglich, E., Ostwald, M., Denef, K., Paustian, K., 2013. Methods for the quantification of GHG emissions at the landscape level for developing countries in smallholder contexts. Environmental Research Letters 8, 1-9.

Ministry for Primary Industries, 2019. Methodology for calculation of New Zealand's agricultural greenhouse gas emissions. Version 5 MPI Technical Paper No: 2019/18. This publication is available on the Ministry for Primary Industries website at http://www.mpi.govt.nz/news-and-resources/publications/.

Moe, P.W., Tyrrell, H.F., 1979. Methane production in dairy cows. Journal of Dairy Science 62, 1583-1586. 
Monaghan, R.M., de Klein, C.A.M., 2014. Integration of measures to mitigate reactive nitrogen losses to the environment from grazed pastoral dairy systems. The Journal of Agricultural Science, 1-12.

Murray, R.M., Bryant, A.M., Leng, R.A., 1976. Rates of production of methane in the rumen and large intestines of sheep. British Journal of Nutrition 36, 1-14.

Myhre, G., Shindell, D., Bréon, F.-M., Collins, W., Fuglestvedt, J., Huang, J., Koch, D., Lamarque, J.-F., Lee, D., Mendoza, B., Nakajima, T., Robock, A., Stephens, G., Takemura, T., Zhang, H., 2013. Anthropogenic and natural radiative forcing. In: Stocker, T.F., Qin, D., Plattner, G.-K., Tignor, M., Allen, S.K., Boschung, J., Nauels, A., Xia, Y., Bex, V., Midgley, P.M. (Eds.), Climate Change 2013: The Physical Science Basis. Contribution of Working Group I to the Fifth Assessment Report of the Intergovernmental Panel on Climate Change. Cambridge University Press, Cambridge, United Kingdom and New York, NY, USA.

Nielsen, N.I., Volden, H., Åkerlind, M., Brask, M., Hellwing, A.L.F., Storlien, T., Bertilsson, J., 2013. A prediction equation for enteric methane emission from dairy cows for use in NorFor. Acta Agriculturae Scandinavica, Section A - Animal Science 63, 126-130.

Niu, M., Kebreab, E., Hristov, A.N., Oh, J., Arndt, C., Bannink, A., Bayat, A.R., Brito, A.F., Boland, T., Casper, D., Crompton, L.A., Dijkstra, J., Eugene, M.A., Garnsworthy, P.C., Haque, M.N., Hellwing, A.L.F., Huhtanen, P., Kreuzer, M., Kuhla, B., Lund, P., Madsen, J., Martin, C., McClelland, S.C., McGee, M., Moate, P.J., Muetzel, S., Munoz, C., O'Kiely, P., Peiren, N., Reynolds, C.K., Schwarm, A., Shingfield, K.J., Storlien, T.M., Weisbjerg, M.R., Yanez-Ruiz, D.R., Yu, Z., 2018. Prediction of enteric methane production, yield, and intensity in dairy cattle using an intercontinental database. Glob Chang Biol 24, 33683389.

NRC, 2001. National Research Council. Nutrient Requirements for Dairy Cattle. Seventh Revised Edition. National Academy Press, Washington, DC.

O'Brien, D., Shalloo, L., Grainger, C., Buckley, F., Horan, B., Wallace, M., 2010. The influence of strain of Holstein-Friesian cow and feeding system on greenhouse gas emissions from pastoral dairy farms. Journal of Dairy Science 93, 3390-3402.

Olesen, J.E., Petersen, B.M., Berntsen, J., Hansen, S., Jamieson, P.D., Thomsen, A.G., 2002. Comparison of methods for simulating effects of nitrogen on green area index and dry matter growth in winter wheat. Field Crops Research 74, 131-149.

Olesen, J.E., Schelde, K., Weiske, A., Weisbjerg, M.R., Asman, W.A.H., Djurhuus, J., 2006. Modelling greenhouse gas emissions from European conventional and organic dairy farms. (Special Issue: Mitigation of greenhouse gas emissions from livestock production). Agriculture, Ecosystems and Environment 112, 207-220.

Palliser, C.C., Woodward, S.L., 2002. Using models to predict methane reduction in pasturefed dairy cows. In: Rizzoli, A.E., Jakeman, A.J. (Eds.), Integrated Assessment and Decision Support, Proceedings of the 1st Biennial Meeting of the iEMSs, Lugano, Switzerland, pp. 162-167.

Pellerin, S., Bamière, L., Angers, D., Béline, F., Benoit, M., Butault, J.-P., Chenu, C., Colnenne-David, C., De Cara, S., Delame, N., Doreau, M., Dupraz, P., Faverdin, P., Garcia-Launay, F., Hassouna, M., Hénault, C., Jeuffroy, M.-H., Klumpp, K., Metay, A., Moran, D., Recous, S., Samson, E., Savini, I., Pardon, L., Chemineau, P., 2017. 
Identifying cost-competitive greenhouse gas mitigation potential of French agriculture. Environmental Science \& Policy 77, 130-139.

Phetteplace, H.W., Johnson, D.E., Seidl, A.F., 2001. Greenhouse gas emissions from simulated beef and dairy livestock systems in the United States. Nutrient Cycling in Agroecosystems 60, 99-102.

Petersen, S.O., Olsen, A.B., Elsgaard, L., Triolo, J.M., Sommer, S.G., 2016. Estimation of Methane Emissions from Slurry Pits below Pig and Cattle Confinements. PLOS ONE 11, e0160968.

Ramin, M., Huhtanen, P., 2013. Development of equations for predicting methane emissions from ruminants. Journal of Dairy Science 96, 2476-2493.

Rinne, M., Kuoppala, K., Vanhatalo, A., Huhtamäki, T., Nousiainen, J., Huhtanen, P., 2017. Finnish feed evaluation system and Feed Tables. Proceedings of the $8^{\text {th }}$ Nordic Feed Science Conference, 97-102. Uppsala, Sweden.

Salètes, S., Fiorelli, J.-L., Vuichard, N., Cambou, J., Olesen, J.E., Hacala, S., Sutton, M., Fuhrer, J., Soussana, J.-F., 2004. Greenhouse gas balance of cattle breeding farms and assessment of mitigation options. In: Weiske, A. (Ed.), Proceedings of the international conference: Greenhouse gas emissions from agriculture mitigation options and strategies, Institute for Energy and Environment, Leipzig, Germany, pp. 203-208.

Sauvant, D., Eugène, M., Giger-Reverdin, S., Archimède, H., Doreau, M., 2014. Relationship between $\mathrm{CH}_{4}$ and urinary $\mathrm{N}$ outputs in ruminants fed forages: a meta-analysis of the literature. Animal Production Science 54, 1423-1427.

Sauvant, D., Giger-Reverdin, S., Eugène, M., 2018. Enteric methane emissions. In: Sauvant, D., Delaby, L., Nozière, P. (Eds.), INRA Feeding System for Ruminants, Wageningen Academic Publishers, Wageningen, Netherlands, pp. 209-212.

Sauvant, D., Nozière, P., 2016. Quantification of the main digestive processes in ruminants: the equations involved in the renewed energy and protein feed evaluation systems. Animal 10, 755-770.

Schils, R.L.M., de Haan, M.H.A., Hemmer, J.G.A., van den Pol-van Dasselaar, A., de Boer, J.A., Evers, A.G., Holshof, G., van Middelkoop, J.C., Zom, R.L.G., 2007. DairyWise, a whole-farm dairy model. Journal of Dairy Science 90, 5334-5346.

Schils, R.L.M., Ellis, J.L., de Klein, C.A.M., Lesschen, J.P., Petersen, S.O., Sommer, S.G., 2012. Mitigation of greenhouse gases from agriculture: role of models. Acta Agriculturae Scandinavica. Section A, Animal Science 62, 212-224.

Schils, R.L.M., Verhagen, A., Aarts, H.F.M., Kuikman, P.J., Šebek, L.B.J., 2006. Effect of improved nitrogen management on greenhouse gas emissions from intensive dairy systems in the Netherlands. Global Change Biology 12, 382-391.

Schils, R.L.M., Verhagen, A., Aarts, H.F.M., Sebek, L.B.J., 2005. A farm level approach to define successful mitigation strategies for $\mathrm{GHG}$ emissions from ruminant livestock systems. Nutrient Cycling in Agroecosystems 71, 163-175. 
Smith, P., Martino, D., Cai, Z., Gwary, D., Janzen, H., Kumar, P., McCarl, B., Ogle, S., O’Mara, F., Rice, C., Scholes, B., Sirotenko, O., Howden, M., McAllister, T., Pan, G., Romanenkov, V., Schneider, U., Towprayoon, S., 2007. Policy and technological constraints to implementation of greenhouse gas mitigation options in agriculture. Agriculture, Ecosystems and Environment 118, 6-28.

Sommer, S.G., Petersen, S.O., Møller, H.B., 2004. Algorithms for calculating methane and nitrous oxide emissions from manure management. Nutrient Cycling in Agroecosystems $69,143-154$.

Torrent, J., Johnson, D.E., 1994. Methane production in the large intestine of sheep. In: Aguilera, J.F. (Ed.), Energy Metabolism of Farm Animals. CSIC, Granada, Spain, pp. 391-394.

van der Weerden, T.J., Luo, J., de Klein, C.A.M., Hoogendoorn, C.J., Littlejohn, R.P., Rys, G.J., 2011. Disaggregating nitrous oxide emission factors for ruminant urine and dung deposited onto pastoral soils. Agriculture, Ecosystems and Environment 141, 426-436.

van Lingen, H.J., Niu, M., Kebreab, E., Valadares Filho, S.C., Rooke, J.A., Duthie, C.-A., Schwarm, A., Kreuzer, M., Hynd, P.I., Caetano, M., Eugène, M., Martin, C., McGee, M., O’Kiely, P., Hünerberg, M., McAllister, T.A., Berchielli, T.T., Messana, J.D., Peiren, N., Chaves, A.V., Charmley, E., Cole, N.A., Hales, K.E., Lee, S.-S., Berndt, A., Reynolds, C.K., Crompton, L.A., Bayat, A.-R., Yáñez-Ruiz, D.R., Yu, Z., Bannink, A., Dijkstra, J., Casper, D.P., Hristov, A.N., 2019. Prediction of enteric methane production, yield and intensity of beef cattle using an intercontinental database. Agriculture, Ecosystems and Environment 283, 106575.

Van Soest, P.J., 1994. Nutritional Ecology of the Ruminant. Cornell University Press, Ithaca, New York.

Waghorn, G.C., 2007. What is dietary metabolisable energy? Proceedings of the New Zealand Grassland Association 69, 153-159.

Warner, D., Bannink, A., Hatew, B., van Laar, H., Dijkstra, J., 2017. Effects of grass silage quality and level of feed intake on enteric methane production in lactating dairy cows. Journal of Animal Science 95, 3687-3699.

Wheeler, D.M., Ledgard, S.F., de Klein, C.A.M., 2008. Using the OVERSEER nutrient budget model to estimate on-farm greenhouse gas emissions. Australian Journal of Experimental Agriculture 48, 99-103.

Wilkerson, V.A., Casper, D.P., Mertens, D.R., 1995. The prediction of methane production of Holstein cows by several equations. Journal of Dairy Science 78, 2402-2414.

Yamulki, S., Jarvis, S.C., Owen, P., 1999. Methane emission and uptake from soils as influenced by excreta deposition from grazing animals. Journal of Environmental Quality $28,676-682$. 